\title{
Hydrological and archaeological studies to detect the deterioration of Edfu temple in Upper Egypt due to environmental changes during the last five decades
}

\author{
Hanaa A.Megahed ${ }^{1}$ \\ Received: 18 June 2020 / Accepted: 21 September 2020 / Published online: 6 November 2020 \\ (c) Springer Nature Switzerland AG 2020
}

\begin{abstract}
Archaeological sites in Upper Egypt, especially Edfu Temple, are considered a wealth of human civilization and are irreplaceable. Deterioration of archaeological sites due to environmental changes in Edfu city include disintegration and exfoliation of stones, dissolution of building materials, loss of moral paintings, crystallization of salts in walls and columns, stone bleeding, destruction of wall paintings and texts, decreasing of durability of monumental stones, and discolouring. Recently, the archaeological field has received a lot of interest from Remote Sensing (RS) and Geographic Information Systems (GIS) users to observe the impact of environmental changes on archaeological sites during long periods. CORONA, LANDSAT, and SENTINEL-2A satellite images are our tools in detecting the changes around the study area and creating innovative solutions. Results from the analysis conducted suggest that most of the environmental changes in the study area are caused by uncontrolled urban sprawling and rising groundwater levels due to agricultural and urban expansion. The proximity of agricultural lands to archaeological areas has also affected the rise in groundwater levels. This has also played an important role in the transfer of chemical contaminants with the leaking water of soil to these archaeological sites, resulting in the growth of salt crystals. In this research, the environmental hazards and their effects are being observed for the archaeological sites of Edfu city (Upper Egypt). A comprehensive analysis has been conducted for the Horus Temple considering its building material, soil characteristics and environmental setting. Finally, we have created some models to protect the archaeological sites from environmental changes by the integration of remote sensing and GIS techniques.
\end{abstract}

Keywords Deterioration · Hydrological studies · Archaeology · Remote sensing · GIS · Edfu · Egypt

\section{Introduction}

Many years ago; Egypt was rich in movable cultural items such as artifacts, as well as immovable cultural heritage monuments such as historical and artistic sites. Like many of the developing countries in Africa; urban sprawling and agricultural expansion are a real phenomenon in Egypt. The increasing danger to the temples around the banks of the Nile due to increasing groundwater rises as a result of agricultural and urban expansion [1-3]. The Nile Valley of Egypt is one of the oldest agricultural areas in the world and has been under continuous cultivation for at least 5000 years [4-7]. These lands became completely too permanent irrigation after the building of the High Dam, where water is available at any time during the year, generating two or three crops each year $[8,9]$. The protection of cultural heritage sites is a significant issue specifically for lands subject to a long period of human activity, possibly adversely influencing heritage properties and their

$\triangle$ Hanaa A.Megahed, hanaanarss@yahoo.com | 'Department of Geology, National Authority for Remote Sensing and Space Sciences (NARSS), Cairo 1564, Egypt. 
environment thus degrading or altering the historical landscape and archaeological features.

The hydrological and hydrochemical analysis of groundwater alongside the historical and archaeological research studies are important applications in studying cultural heritage management and the effect of groundwater on archaeological sites [10-24]. Remote sensing indices, hydrogeological settings, and spatial autocorrelation analysis are considered effective methods of detecting the environmental changes around archaeological areas. Finally, the integration of remote sensing and geographic information system techniques will allow us to establish some of the archaeological sites' protection models [25-42].

Remote Sensing (RS) and Geographic Information System (GIS) allows cultural resource managers, historians, planners, and engineers to catalogue and assess the organizational and structural patterns of such sites, and determine sustainable tourism and urban development options within their regions [43-46] Early remote sensing applications in archaeology started in the 1920s [47]. In archaeology, aerial photography was primarily used to view features on the surface of the earth, which is difficult if not impossible to visualize from ground level [48]. Today the remote sensing technique is used as an operational technique for the identification of archaeological surface and underground remains $[49,50]$ as well as for the documentation, monitoring, and preservation of cultural heritage sites [53].

Change detection of the environmental is a dynamic method related to landscape change driving forces such as the environment, geography, and many others that affect the archaeological sites on multiple spatial and temporal scales. Understanding and analysing these driving forces and their interrelationships are a major topic. Also, the temporal components of spatial urbanization and rising groundwater levels can be more simply identified through GIS and remote sensing models [54]. In particular, the availability of low-cost, high-resolution satellite images permits the acquisition of data covering large areas, including the same areas over multiple periods up to a recent perspective of the landscape. On the other hand, the development of these techniques has advanced archaeological site documentation in a rapidly urbanizing system, investigating the looting process and supporting guide archaeological preservation works [55]. Remote sensing offers a trusted significant source of information, and methods are being developed for small and large-scale operational detecting of environmental problems [56]. However, additional in situ samples and reference field spectra can aid in finding new techniques and test not only the accuracy of the final image analysis output [57]. The scientific satellite radar data for archaeological studies was possible owing to increased availability started in the early 1990 s of Synthetic Aperture Radar (SAR) imagery in the Remote Sensing Agencies [58]. Together with surface surveys, remote sensing data can collaborate to form a better image of the present and prehistoric landscape cultural heritage locations [59]. Nowadays, Optical, radar data, and GIS techniques are used to develop zoned archaeological hazard maps that will guide planners and developers regarding the importance of archaeological remains across the cities and where building activity should be strictly regulated or allowed [60].

Spatial analysis and geographic information system techniques are important techniques that can be used for predictive models in preventive archaeology. Each of these techniques can play a major role in archaeological studies in the Decision Support System (DSS) and in providing useful data to reduce archaeological risks. In this research, the main aim of the study is to identify various causes of deterioration, and the factors and mechanisms affecting the Horus Temple from the different groundwater effects.

\subsection{Study area}

On the west bank of the Nile, Edfu city is situated in Upper Egypt about $100 \mathrm{~km}$ south of Luxor [61]. Its large temple (Horus) from the Ptolemaic age (about 300-30 BC) is dedicated to the falcon-headed god Horus, making it a famous city [62]. The temple is considered to be one of the most impressive holy buildings and the best-preserved temple of Egyptian antiquity. The construction activities started in about $237 \mathrm{BC}$ and ended in $57 \mathrm{BC}$, after one hundred eighty years [63, 64] (Fig. 1a, b, C).

\subsection{The archaeological description of the temple}

The Temple is dedicated to Horus, the Behdetite [65], a falcon god who is usually worshiped as a man with the head of a falcon [66]. The temple is important because it's large and well-preserved [67]. The inscriptions that cover the walls of Edfu Temple are considered the most valuable sources on Ptolemaic Egypt; they offer a wealth of information, mainly about religion, also administration, political history, and other topics [68]. The Edfu inscriptions transmit ideas that come from the oldest epochs of Pharaonic history [69]. Furthermore, the temple inscriptions can be taken as a compendium of the Egyptian lifestyle [70, 71]. Three main phases are observed in the temple building, the original nucleus, itself a complete temple with a hypostyle hall [72], two other halls, a sanctuary, numerous side chapels and the third, the forecourt foundations, the stone enclosure wall, and the pylons. However, until 57 B.C, the decoration of the temple does not appear to have been completed, and the great doors 


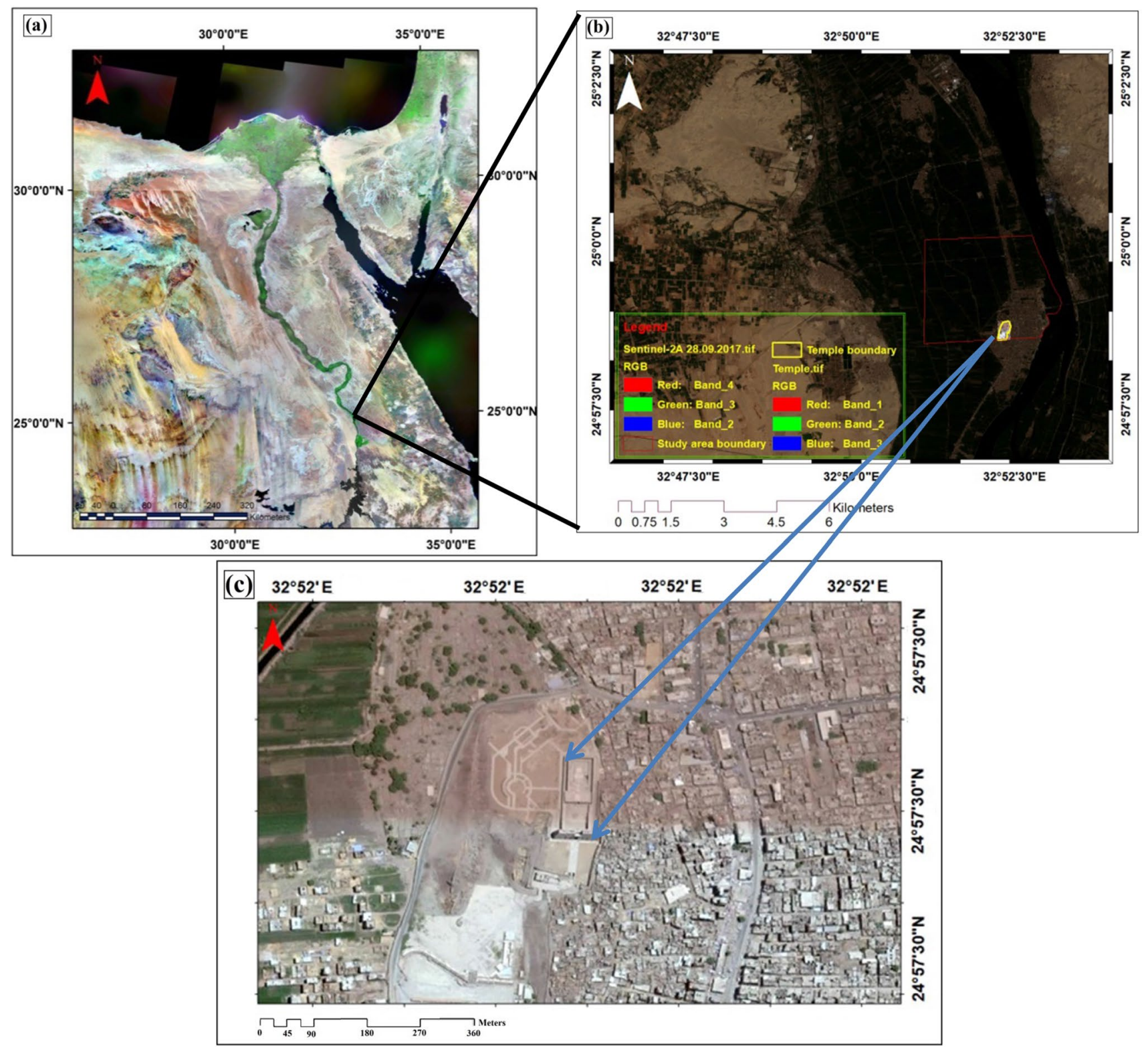

Fig. 1 Landsat 7 image of Egypt (a), Sentinel 2-A 2019 showing the study area (b), and Google Earth plus 2019 of The Horus Temple (c)

of the pylon were not hung [73]. The whole temple took about 180 years to complete. This impressive building lay within a vast enclosure oriented from south to north. Before the Pylon, there were originally two masts and an obelisk which no longer exists now. Over the main door and between the wings of the Pylon was the Balcony of the Falcon, reached between the Forecourt by stairs in the eastern side of the Pylon [74]. With a colonnade of thirty-two columns to south, east, and west, and with two doors in each of its east and west walls, the Forecourt was a vast uncovered court. On the north side of the Forecourt lay the Pronaos or Outer Hypostyle, the great court as it was most commonly called. It was both higher and wider than the rest of the temple to the north of it and contained twelve enormous columns. The south wall was composed of a screen wall, about half the height of the hall, with three engaged columns on either side of the entrance $[75,76]$. The north wall of the Central Hall was occupied by the facade of the Sanctuary and the doors of the corridor that surround it. The sanctuary or Holy of Holies was surrounded by the sanctuary, and separated from it by a corridor [77, 78], (Fig. 2a and b). 

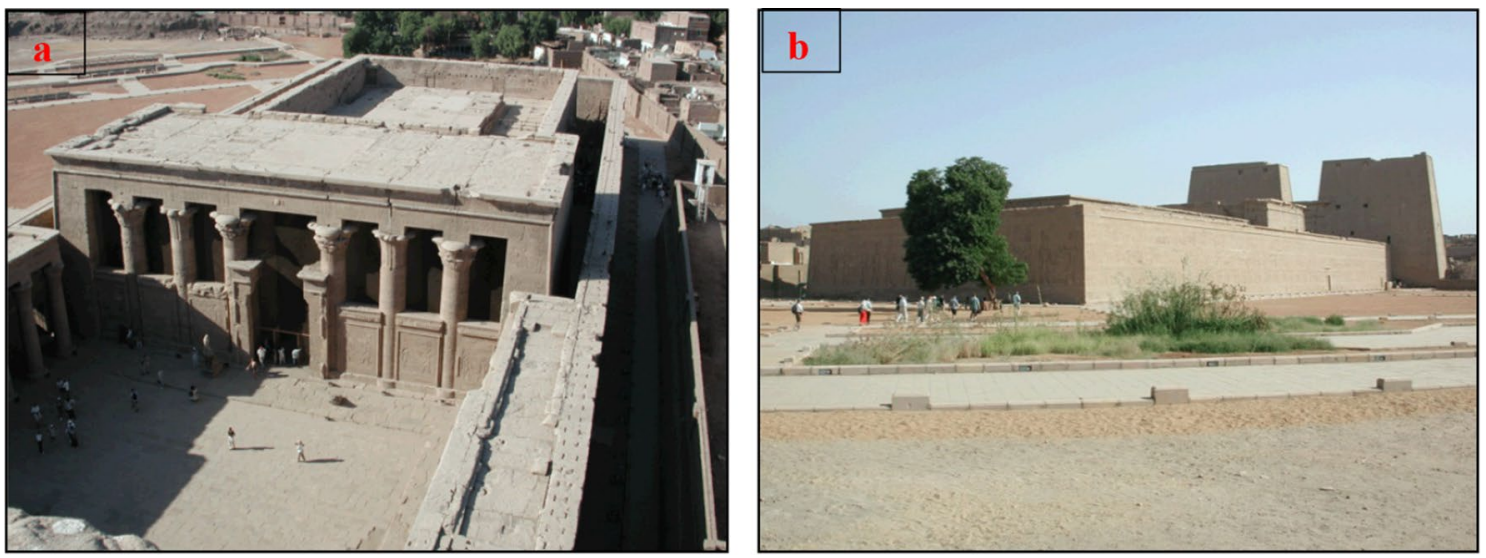

Fig. 2 Overview of the court and pronaos of the temple seen from the eastern side (a), and the northwest side of the temple (https://www. egypttoursportal.com/egypt-day-trips/aswan-tours/tour-to-kom-ombo-edfu-temples-from-aswan/) (b)

\subsection{Problem definition}

The most important temple site deterioration factors are the Nile flow, agricultural drainage, low-level location, and surrounding urban sewage. Most of the historical structures (Pharaonic, Greco Roman, and Islamic periods) have been dependent on the limestone as an essential building material for long periods in Lower and Upper Egypt. Many of the limestone monuments have suffered serious damage due to various deterioration factors in Egypt [79] (Fig. 3). Also, the geological setting is one of the top deterioration factors in the study area that include four stratigraphic formations (Edfu, Esna shale, Armant and Issawia Formations) (Fig. 4a). The temple belonged to the Cretaceous period [80] and was built on a hill of silt and clay, the study area was situated through the alluvial plains of the Nile, surrounded by dense plateaus covered by Eocene calcareous and Paleocene shale (Fig. 4b, c).

Egypt is one of the arid zones of North Africa with two main freshwater systems; the River Nile and groundwater [81]. The groundwater system in the study area is highly influenced by the irrigation system, unplanned urban sprawling and the Nile flow. Groundwater quality around the Horus temple is characterized by a high salinity index [82]. Also, soil characteristics are an important factor that must be studied to detect the groundwater effects on the temple structure, also the types of salts in the soil and their proportions to decide how these components pose a danger to the archaeological remains. On the other hand, we can derive the effect of water suction pressure migrating through the building foundations (estimated by 4-5 $\mathrm{m}$ from ground surface) by capillary rising (defined by $12.30 \%$ ), and the evaporation rate on the wall surface according to the dominating relative humidity, and air temperature [83].

\section{Material and method}

\subsection{Data collection}

To study the groundwater flow and direction and their impact on the temple site, we have collected the geological map with scale $1 ; 500$ [84] hydrogeological map with scale1:100:000 [85, 86] and Digital Elevation Model extracted from Shuttle Radar Topography Missio (SRTM)
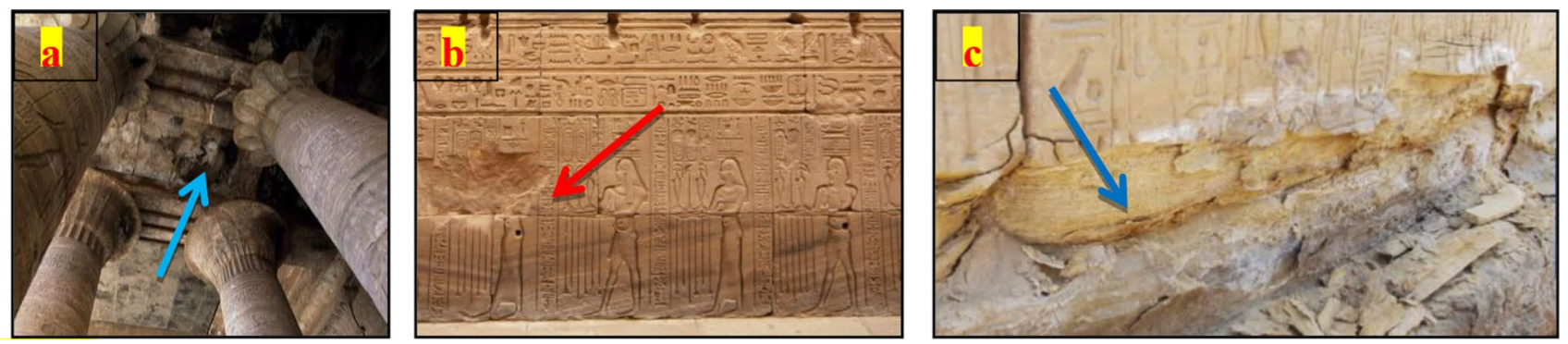

Fig. 3 Examples of the deteriorated areas $(\mathbf{a}, \mathbf{b}$, and $\mathbf{c})$ in the Horus temple resulted from environmental risks around the temple (https:// commons.wikimedia.org/wiki/File:Edfu_Temple_032010_21_d2.jpg)

\section{SN Applied Sciences



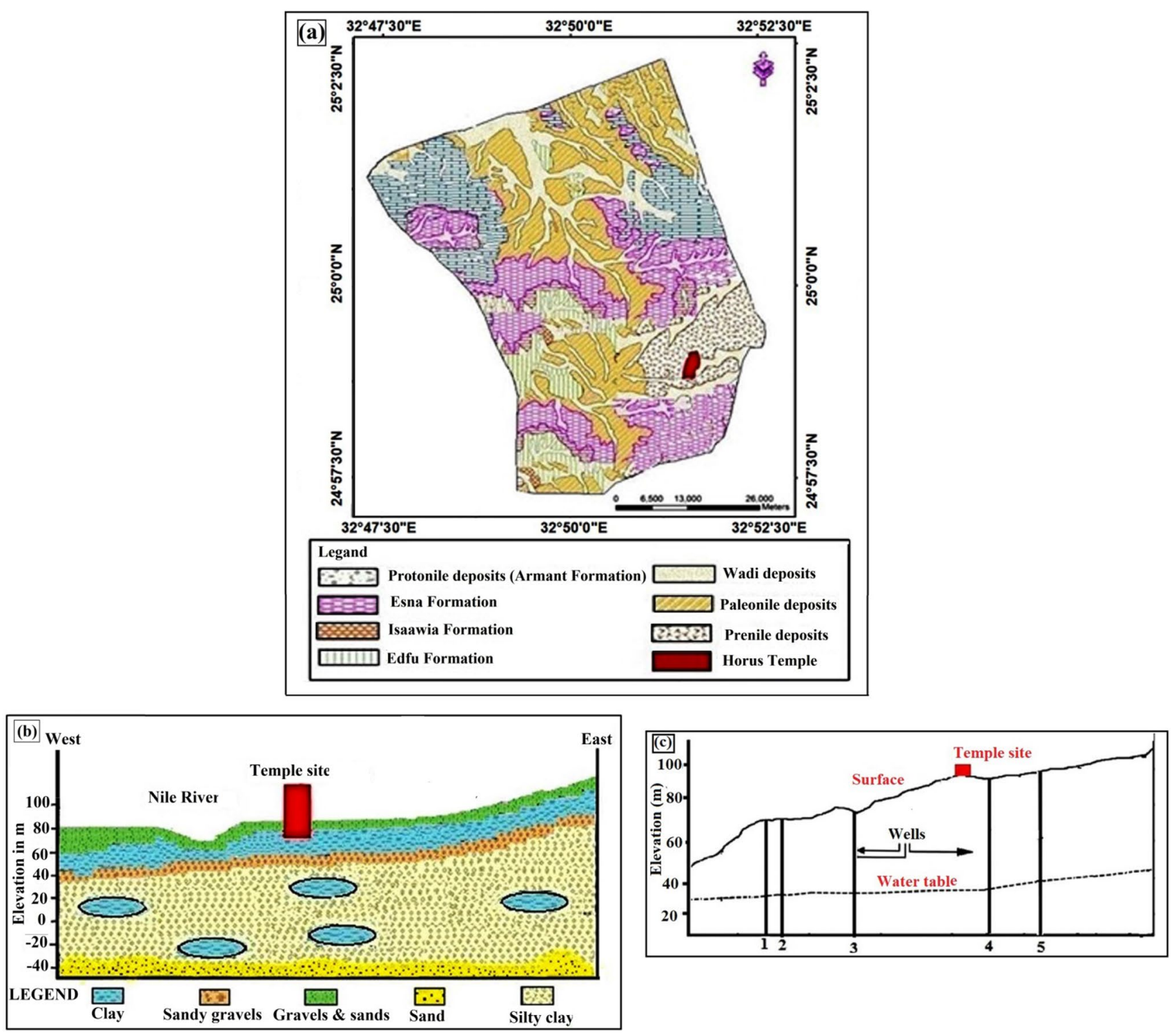

Fig. 4 Geological map of Edfu temple and surrounded area (modified after CONCO, 1987) (a), Litholographic section around Horus Temple (b), and Water table showing the direction of the groundwater flow (c)

to detect the watershed and drinage water system in the study area. Also, we have downloaded and analyzed satellite images from the USGS Earth Explorer and GLCF
(Corona (May 1968), Landsat TM (May 1983), Landsat TM (May 1992), Orbview-3 (May 2004) and Sentinel-2A (May 2019)) (Table 1) to detect urban and agriculture expansion.
Table 1 The satellite images properties for the study area from 1968 and 2019

\begin{tabular}{llllll}
\hline Number & Satellite & Sensor & Resolution $(\mathrm{m})$ & Acquisition date & Source \\
\hline 1 & Corona & KH-4A & 1.8 & May, 1968 & USGS \\
2 & Landsat 4 & TM & 30 & May, 1983 & GLCF \\
3 & Landsat5 & TM & 30 & May, 1992 & GLCF \\
4 & Orbview-3 & MS & 1 & May,2004 & USGS \\
5 & Sentinel-2A & 2A & 10 & May,2019 & USGS \\
\hline
\end{tabular}




\section{Methodology}

The hydrological, geological maps analysis and satellite images interpretation were carried out with ArcGIS 10.1 and ENVI 5.1 software to detect the changes in the urban and agriculture areas-based on past and immediate data. The layer stacking, dark subtract, geometric correction, unsupervised classification, supervised classification, post-supervised classifications techniques were carried out using Envi software. Digital Elevation Model of the studied area was generated from the elevation points and the vector contour line (obtained from topographic map scale 1:50,000) using Arc Map V.9.3 software. The main aim of using the topographic maps, or the SRTM DEM data in such case, was to detect the most appropriate areas to put the pumps that will work to collect the groundwater around the archaeological areas. That's because the topographic maps have the contour lines and the high spots layers that help the researchers in detecting the most significant areas (high or low elevated areas). So, according to the extracted digital data from the topographic maps, we can choose the optimal points for the pump-lines that will collect the groundwater around the archaeological areas. The 2D Elevation model and the watershed have been carried out by Soil \& Water Assessment Tool (SWAT) model. Spatial distribution was analysed by Getis-Ord and Hot Spot statistic using Arc GIS software. Recently, many studies have used these tools to detect the amount of urban, agriculture, sprawling areas around the frost and archaeological areas to protect these areas [87-90]. For the present study; the available raster data were firstly converted into vector polygon data to make use of statistical analysis available for vector data. The extracted data were put in separate shapefile layer. The final step is to detect the Getis-ord and Hot spot statistics for all the included vector layers including; agriculture and urban areas through using the Getis-Ord statistic tool, and the Hot Spot tool in ArcGIS software. The calculating of Getis-Ord GI* can be given according to the following statistical equations [91].

$G_{i}^{*}=\frac{\sum_{i=1}^{n} w_{i, j} x_{j}-\bar{X} \sum_{j=1}^{n} w_{i, j}}{\sqrt[5]{\frac{\left[n \sum_{j=1}^{n} w_{i, j}^{2}-\left(\sum_{i=1}^{n} w_{i, j}\right)^{2}\right]}{n-1}}}$

where $x_{i}$ is the attribute value for feature $j, w_{i j}$ is the spatial weight between feature $i$ and $j, n$ is equal to the total number of features and:

$\bar{X}=\frac{\sum_{j=1}^{n} x_{i}}{n}$

$S=\sqrt{\frac{\sum_{j=1}^{n} x_{j}^{2}}{n}-(\bar{X})^{2}}$

The $G_{i}^{*}$ statistic is a \% -score so no further calculations are required.

Band indices techniques have been derived using the built-up and vegetation expressions. The Normalized Difference Built-up Index (NDBI) method enabled to map the
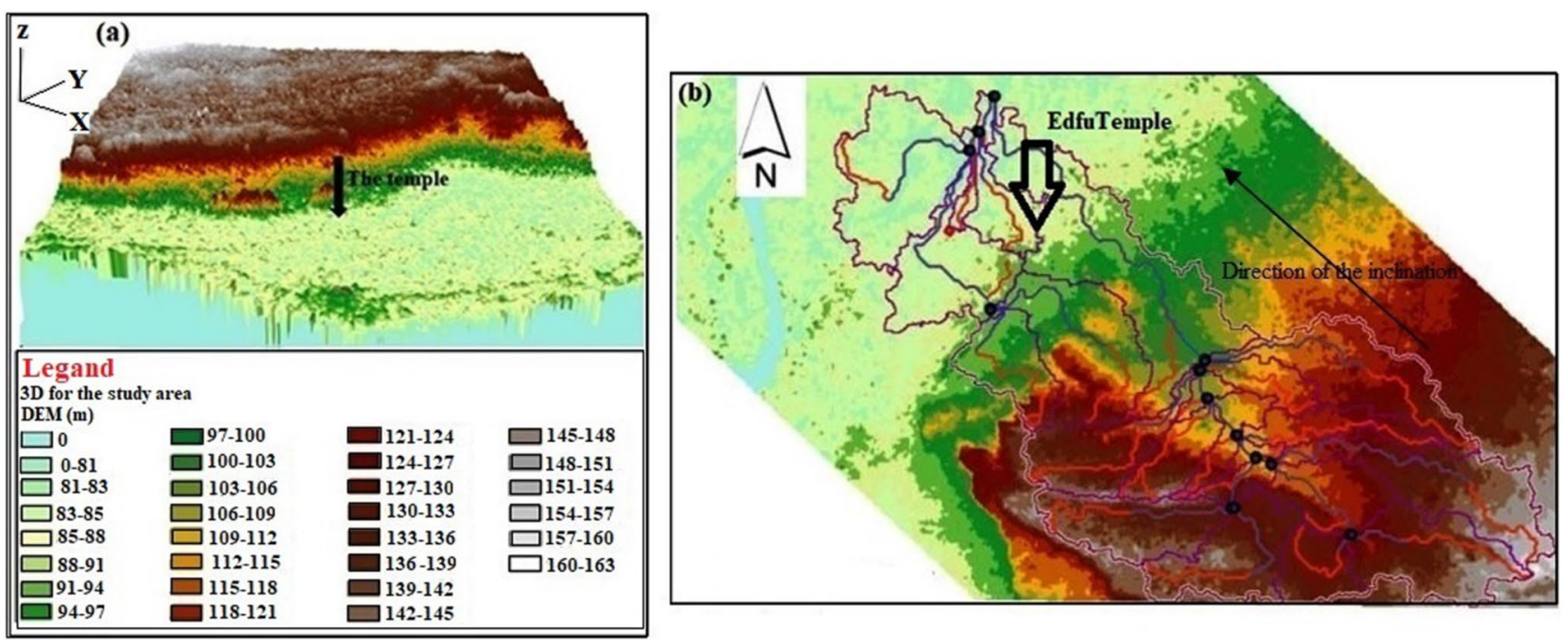

Fig. 5 DEM extracted from SRTM showing 3D of the study area around the temple (a), Watershed delineation by SWAT model and 2D for the study area (b)

\section{SN Applied Sciences}


built-up and bare land in the study area, according to the following equations [92]:

$\mathrm{NDBI}=($ Band $5-$ Band 4$) /($ Band $5-$ Band 4$)$ Landsat TM4, 5

$\mathrm{NDBI}=($ Band $11-$ Band 8)$/($ Band $11-$ Band 8$)$ Sentinel $2-\mathrm{A}$

We also used the Normalized Difference Vegetation Index (NDVI) method to determine whether or not the target being measured includes live green vegetation. The NDVI index depends on the combination of the bands 3 and 4 in TM, and 4, 8 in Sentinel 2, as in the following formula [93].

$\mathrm{NDVI}=($ Band $4-$ Band 3) $/($ Band $4+$ Band 3$)$ Landsat4 TM

$N D V I=($ Band $8-$ Band 4$) /($ Band $8+$ Band 4$)$ Sentinel $2-A$

\section{Results and discussions}

According to the Digital Elevation Model (2D and 3D) and SWAT analysis tool, the temple is situated between 88 and 91 m elevation. It's observed that the direction of the inclination from the southeastern to the northwestern side. Also, the temple is situated inside a basin, and this situation indicated that one of the reasons for rising the groundwater level in the temple area (Fig. 5). To clarify hydrological impacts on the archaeological sites must study hydrochemistry of groundwater and their impact on the temple-bearing soil and archaeological building materials. Figure 6 shows the strategy to study the effect of groundwater levels rising in the temple area. This strategy will support the preservation and protection plan for the study area.

\subsection{Hydrological impacts on the archaeological sites}

There are various environmental factors that might impact archaeological sites. Hydrological processes are considered one of these factors which influence the contained soil and can lead to land deterioration. In the present study, the impacts of hydrological processes, represented by groundwater chemical characteristics, on bearing soil and building material of Edfu archaeological site were investigated. Deterioration of groundwater quality (e.g. high levels of salinity) can lead to soil salinization and corruption of the temple building materials. In the upcoming sections, the evaluation of hydrological processes and their impacts on soil and buildings on Edfu template will be discussed.

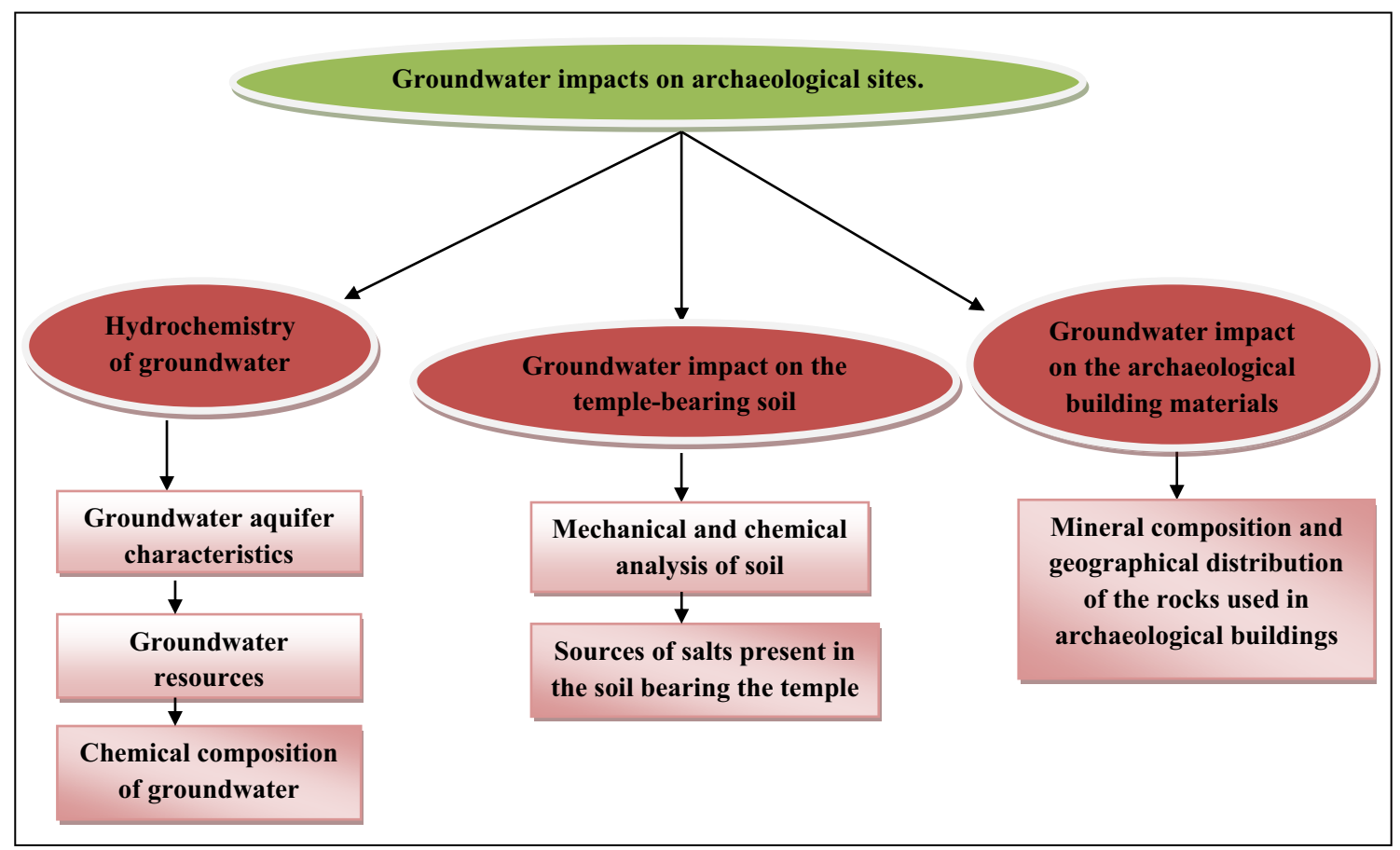

Fig. 6 Flow chart shows the groundwater rise impacts on the Edfu temple 


\subsubsection{Hydrochemical properties of groundwater}

Groundwater hydrochemical properties include characteristics of groundwater aquifers, groundwater resources, and their chemical and physical compositions.

Groundwater aquifers in the study area are represented by two hydrologically connected aquifers which are the semi-confined aquifer, and the unconfined aquifer which covers the lower range of the Nile River [94, 95]. The semiconfined aquifer consists of two layers, the upper layer of the clay-silt, which is characterized by its low permeability and reaches between 0.4 and $1 \mathrm{~m} /$ day and an average thickness of $8 \mathrm{~m}$. As for the lower layer, it is sand and gravel. The thickness of this layer is $150 \mathrm{~m}$. This layer is the main groundwater aquifer in the Nile Valley. The depths of groundwater in the aquifer vary between 3 and $100 \mathrm{~m}$ and the thickness of the aquifer layers is between 25 and $60 \mathrm{~m}$. The volume of water drawn annually from the underground aquifer is about 602,456 cubic meters, so the

Table 2 Classification of risk degree of salts concentrations on archaeological buildings as per the World Health Organization (WHO 2004)

\begin{tabular}{llll}
\hline Elements & Low risk & Medium risk & High risk \\
\hline $\begin{array}{l}\text { Hydrogen ions con- } \\
\text { centrations }(\mathrm{pH})\end{array}$ & $5.5-6.5$ & $4.5-5.5$ & 4.5 Less than \\
$\begin{array}{l}\text { Carbonate } \\
\text { Sulphate }\end{array}$ & $15-30$ & $30-60$ & More than 60 \\
Magnesium & $200-600$ & $600-2000$ & More than 2000 \\
Nitrate & $300-100$ & $300-1500$ & More than 1500 \\
\hline
\end{tabular}

study area is one of the largest areas in the exploitation of groundwater $[96,97]$.

Groundwater resources come not only from the Nile River, but also from fossil sources various resources include irrigation water, agricultural drainage, and wastewater [98]. The proximity of the Edfu Temple to the Nile River and the construction of the High Dam raised the groundwater level, where large amounts of water were stored behind the dam, leaking from it and leaching into the main underground aquifer, and in turn leaking irrigation water into the soil [99].

Those who have studied the Egyptian monuments [100-104] report that the danger threatening the archaeological buildings is the salts transferred from the groundwater to the soil supporting the monuments and the most lethal salts discovered in this groundwater are: Sodium Chloride, Sodium Sulfate, Sodium Nitrate, Sodium Carbonate and the hydrogen ion concentrations $(\mathrm{pH})$ (Table 2).

Twenty-three samples from underground wells in various locations in the study area were collected and analyzed. The samples were stored in well dried clean plastic bottles which were filled with water; leave no air in, to avoid change in the partial pressure of $\mathrm{CO} 2$. The bottles were labeled with waterproof markers and then they were brought directly to the laboratory for analysis. Sodium contents were determined using flame photometer technique. Other cations were measured using a spectrophotometer. Chloride and sulphate concentrations were determined calorimetrically and bicarbonate concentration was determined by titration method. The concentration of trace elements $(\mathrm{Fe}++, \mathrm{Mn}++)$ was determined using a spectrophotometer. It was found that Potassium, Carbonate,
Table 3 Average

concentrations of studied groundwater samples compared with the standard of the World Health Organization (WHO 2004)

\begin{tabular}{lll}
\hline Elements & $\begin{array}{l}\text { World Health Organization } \\
(\mathrm{WHO})\end{array}$ & $\begin{array}{l}\text { Average concentrations } \\
\text { of studied groundwater } \\
\text { samples }\end{array}$ \\
\hline Total Dissolved Solids (TDS) & $1000-1500$ & 1822.27 \\
Hydrogen ions concentrations $(\mathrm{pH})$ & $5.5-6.5$ & 7.6 \\
Electrical Conductivity (EC) & 1400 & 1095.75 \\
Calcium $(\mathrm{Ca}+2)$ & $75-100$ & 102.92 \\
Magnesium $(\mathrm{Mg}+2)$ & $125-300$ & 41.08 \\
Sodium $(\mathrm{Na}+)$ & 200 & 142.49 \\
Potassium $(\mathrm{K}+)$ & - & 7.43 \\
Bicarbonate $\left.(\mathrm{HCO})_{3}\right)$ & - & 405.27 \\
Chloride $(\mathrm{Cl}-)$ & $25-600$ & 170.06 \\
Sulfate $(\mathrm{SO} 4-2)$ & $250-400$ & 151.97 \\
Lead $\left(\mathrm{Pb}{ }^{+}\right)$ & 0 & 0 \\
Cadmium $(\mathrm{Cd})$ & 0.01 & 0 \\
Manganese $(\mathrm{Mn}+)$ & $0.1-0.5$ & 0.41 \\
Iron (Fe+) & $0.3-1$ & 0.06 \\
Zinc $(\mathrm{Zn})$ & $0.5-15$ & 0.04 \\
\hline
\end{tabular}


Chlorides, hydrogen ion concentrations $(\mathrm{pH})$ and Electrical Conductivity $(E C)$ were greater than the World Health Organization standards for safety [105] (Table 3). There is also a relationship between the Total Dissolved Solids (TDS) in groundwater and $\mathrm{pH}$ [106]. An increase in the $\mathrm{pH}$ of groundwater indicates an increase in the percentage of their salt content.

\subsubsection{Groundwater impact on the temple-bearing soil}

The characteristics of the soil bearing the monuments were studied (mechanical and chemical analysis) to identify the types and sources of salts in the soil and how these salts represent a danger to the archaeological buildings.

Ten samples of the temple-bearing soil were collected from the soil profiles and the mechanical analysis by sieve method showed that the average percentage of coarse grain size (very coarse sand, coarse sand, and mediumcoarse sand) was about $40.35 \%$ total samples sizes. As for fine sand, it reaches $6.63 \%$ and clay reaches about $54.2 \%$ which suggests the temple-bearing soil is vulnerable and could cause the temple to fall [107].
Four soil samples were obtained for the chemical analysis (Dissolved salts). Based on the results, the soil analyzed contains a high proportion of soluble salts in water, which in turn leads to soil fragility and disassembly, especially when exposed to rain or a rise in groundwater. Calcium sulfate salt is present in soil samples because the soil was infused with a large proportion of calcium-containing gypsum, which is a low-harm element when compared to rapidly dissolved sodium chloride salts in water, which cause deterioration of archaeological buildings. Dissolved salts in the soil represent a real danger to archaeological buildings, and the higher the salt content in the soil, the greater the risk to the archaeological buildings above this soil. The most important sources of salts found in the soil are chemical fertilizers, salts resulting from the improper use of the materials used for the restoration of monuments and from the decomposition of plants and fungi in the soil [108].

Table 4 The total urban changes in the study area by $\mathrm{M}^{2}$ between 1968 and 2019

\begin{tabular}{|c|c|c|c|c|c|c|c|c|c|}
\hline Class & $\begin{array}{l}\text { Acquisi- } \\
\text { tion date: } \\
\text { May, } 1968 \\
\text { Resolution } \\
1.8 \mathrm{~m}\end{array}$ & $\begin{array}{l}\text { Change } \\
\text { detection } \\
\pm \mathrm{m}^{2}\end{array}$ & $\begin{array}{l}\text { Acquisition } \\
\text { date: } \\
\text { May, } 1983 \\
\text { Resolution } \\
30 \text { m }\end{array}$ & $\begin{array}{l}\text { Change } \\
\text { detection } \\
\pm \mathrm{m}^{2}\end{array}$ & $\begin{array}{l}\text { Acquisition } \\
\text { date: } \\
\text { May, } 1992 \\
\text { Resolution } \\
30 \mathrm{~m}\end{array}$ & $\begin{array}{l}\text { Change } \\
\text { detec- } \\
\text { tion } \\
\pm \mathrm{m}^{2}\end{array}$ & $\begin{array}{l}\text { Acquisition } \\
\text { date: } \\
\text { May, } 2004 \\
\text { Resolution } \\
1 \mathrm{~m}\end{array}$ & $\begin{array}{l}\text { Change } \\
\text { detection } \\
\pm \mathrm{m}^{2}\end{array}$ & $\begin{array}{l}\text { Acquisition } \\
\text { date: } \\
\text { May, } 2019 \\
\text { Resolution } \\
10 \mathrm{~m}\end{array}$ \\
\hline Urban & $111.5 \mathrm{~m}^{2}$ & 261.8 & $373.3 \mathrm{~m}^{2}$ & 231.6 & $604.9 \mathrm{~m}^{2}$ & 138.7 & $743.6 \mathrm{~m}^{2}$ & 1.532 .6 & $2.276 .2 \mathrm{~m}^{2}$ \\
\hline Change \% & & $13.00 \%$ & & $11.40 \%$ & & $5.60 \%$ & & $70.00 \%$ & \\
\hline
\end{tabular}
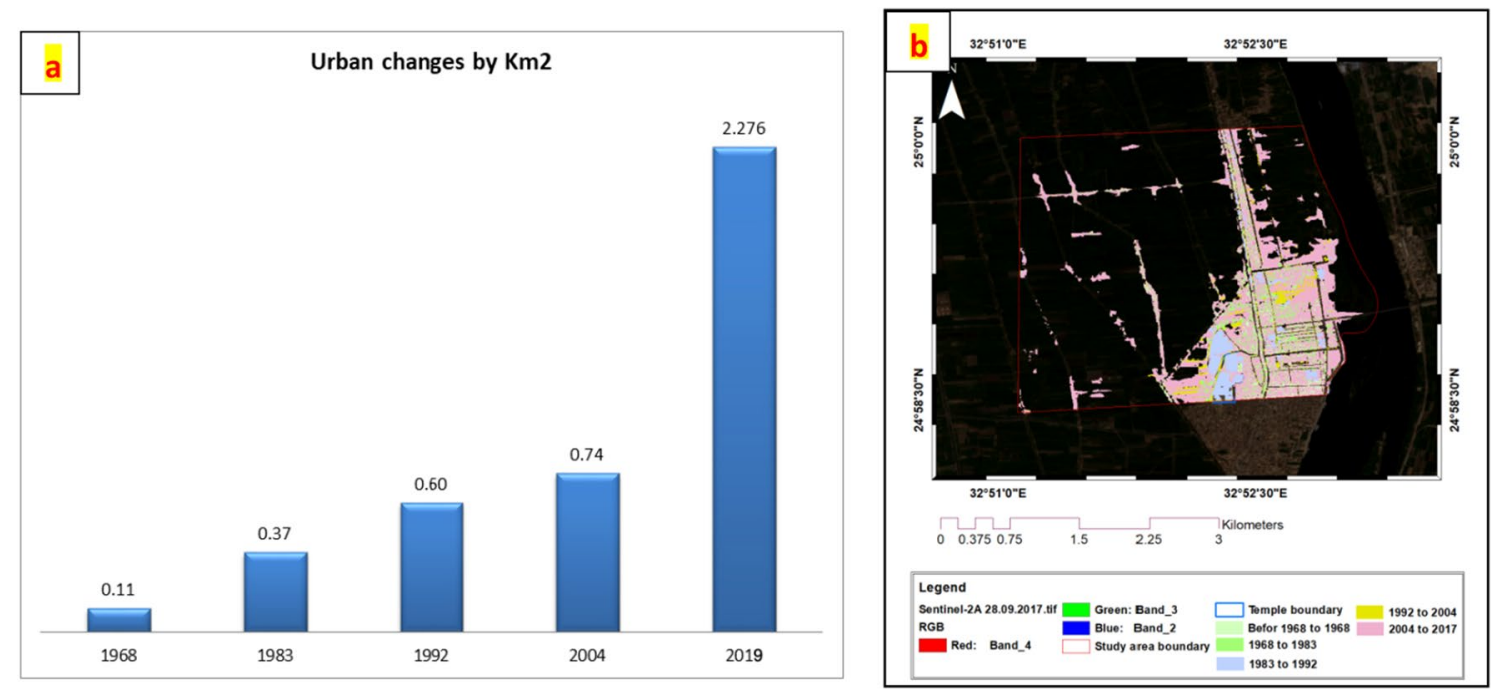

Fig. 7 The changes in the urban area between 1968 (a) and 2019 by graph and Sentinel 2-A Sep 2019 (RGB) (b) 

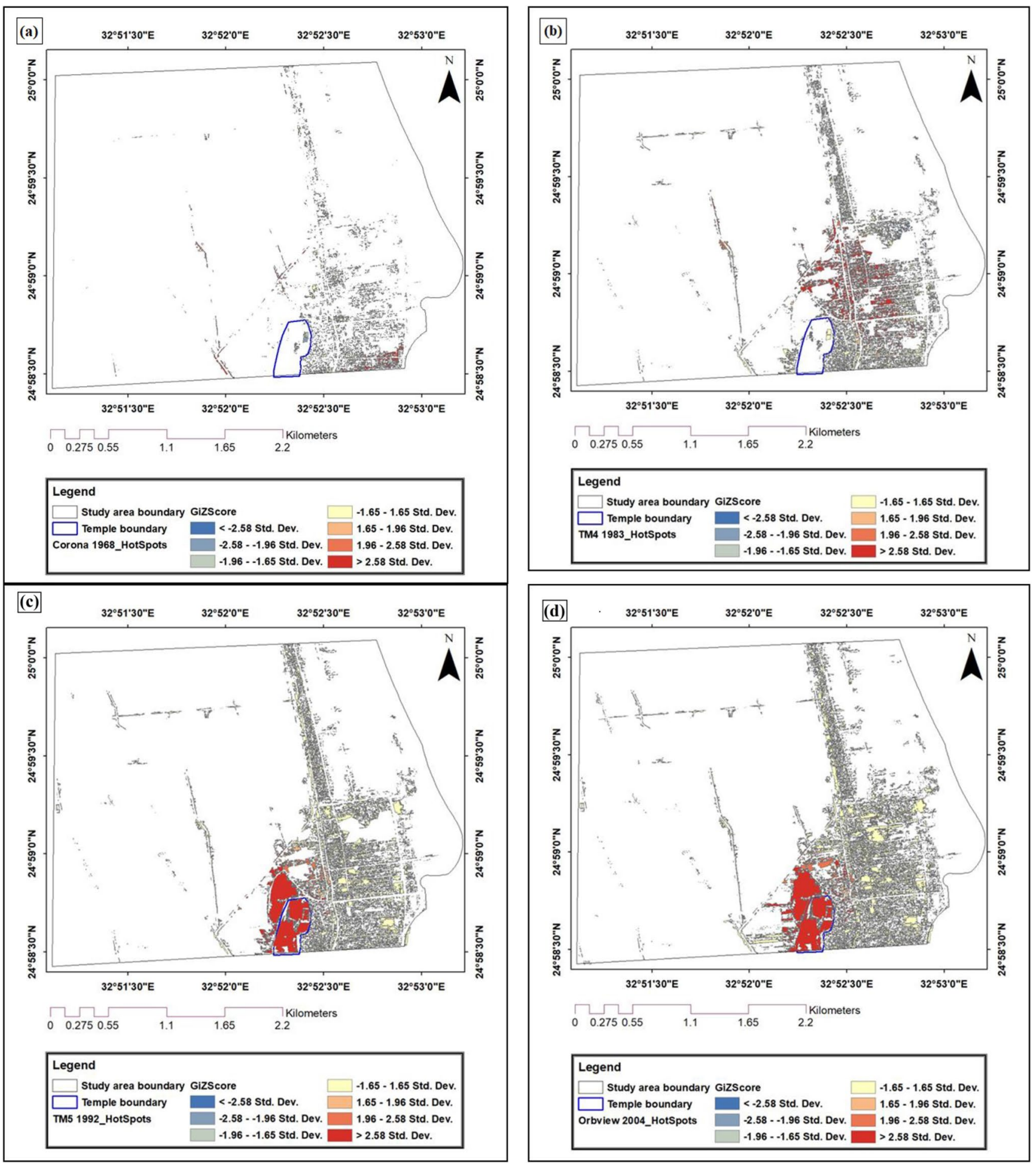

Fig. 8 The changes in the urban area between 1968 (a), 1983 (b), 1992 (c), 2004 (d), and 2017 (e) around the temple by spatial distribution analysing 


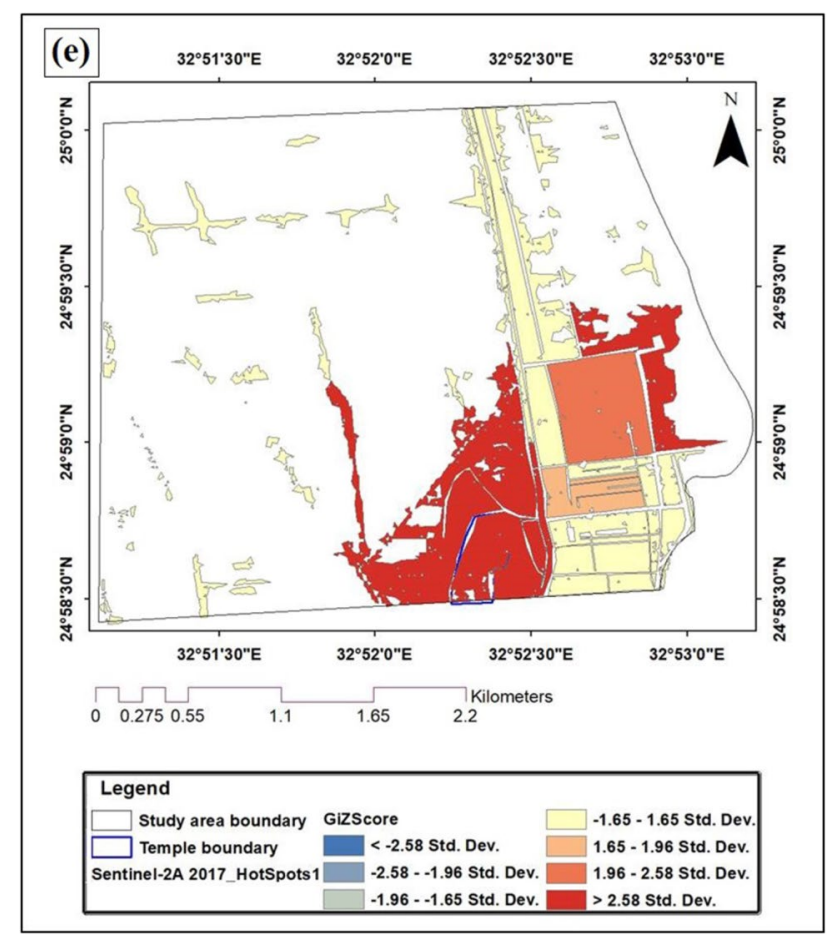

Fig. 8 (continued)

\subsubsection{Groundwater effect on the archaeological building material}

Limestone is considered the major material of archaeological buildings, whether Pharaonic, Greek, Roman, Coptic or Islamic and is largely due to the abundance of limestone in the study area (11 limestone quarries in Sohag Governorate) [109]. Limestone is affected by the surrounding environmental conditions, which appears in the body of the wall, and the colors in drawings and inscriptions [110].

Mineral composition of limestone is mainly calcium carbonate with a small percentage of magnesium, silica, shale, and iron. It is considered the best limestone in a building contains a small percentage of fossils [111]. Some of the minerals inside the rock lead to the formation of low-soluble salt compounds in water such as limestone, which originally consists of calcite and dolomite (calcium carbonate or magnesium carbonate) but they turn into high-soluble salt compounds when connected to water (rainwater or groundwater) and this represents a geomorphological threat to the monuments, although its effect appears in the long term.

4.1.3.1 Change detection (Landuse/landcover) Five satellite images were downloaded at different times from the same area (May 1968, 1983, 2002, 2004, and 2019) to detecting urban encroachment and changes in the vege- tation value in the same agriculture season of the year. The classified images of the five dates were used to calculate differences in the areas cover and observe the changes that occurred in the span of data. In more detail, the analysis of Corona, Landsat TM 4, 5, Orbview-3, and Sentinel-2A imagery revealed that the urban area increased by about $261.8 \mathrm{~m}^{2}$ from 1968 to 1983 . However, the urban area also increased by about $231.6 \mathrm{~m}^{2}$ from 1983 to 1992 . In the same direction, the urban area increased also about $138.7 \mathrm{~m}^{2}$ from 1992 to 2004 , and finally, the built-up area increased by about $1.532 .6 \mathrm{~m}^{2}$ from 2004 to 2019 (Table 4). These changes proved that urban sprawling presented the main direction in the chronology of the changes. The biggest change in the built-up area occurred in the urban area around the temple (Fig. 7a, and b).

On the other hand, the spatial distribution by Getis-Ord statistic and Hot Spot analysis tools showed a Hot Spot area in 1968 present in the east-northern side from the temple. This means that the danger from the built-up area wasn't high. Later, the Hot Spot transferred from the temple to the northern and eastern sides in 1992. This means that the development in the built-up area became more dangerous. In the next era, 2004, the Hot spot area presented directly beside the temple. A new stage is highly affected by the greatest risk that appeared in 2019 when the Hot Spot area surrounded the temple from all sides (Fig. 8a, b, c, d, and e, respectively).

The result of the built-up (Fig. 9a, and b), and the vegetation indices (Fig. 10a, and b), proved that the changes between the 1984 and 2019 images in the built-up area focused around the temple area in the north-eastern side, were enormous.

\section{Recommendation}

Besides the high risk of digging around the temple walls, the ancient method for collecting the groundwater will lead to movement and change in the environment status under the temple which would cause a lot of problems for the archaeological builds. The groundwater table will become lower. The total effect will be that the risk of salinisation will increase. Groundwater is always moving forcibly by gravity from recharge to discharge areas. Groundwater movement in most areas is slow - a few feet per year but in more permeable zones such as channels in the limestone, movement can be as much as several feet per day (https ://www.pubs.usgs.gov/gip/gwruralhomeowner/) (Fig. 11).

Remote sensing models can be used to detect and decrease the environmental risks around the archaeological sites according to UNESCO rules. UNESCO gave 

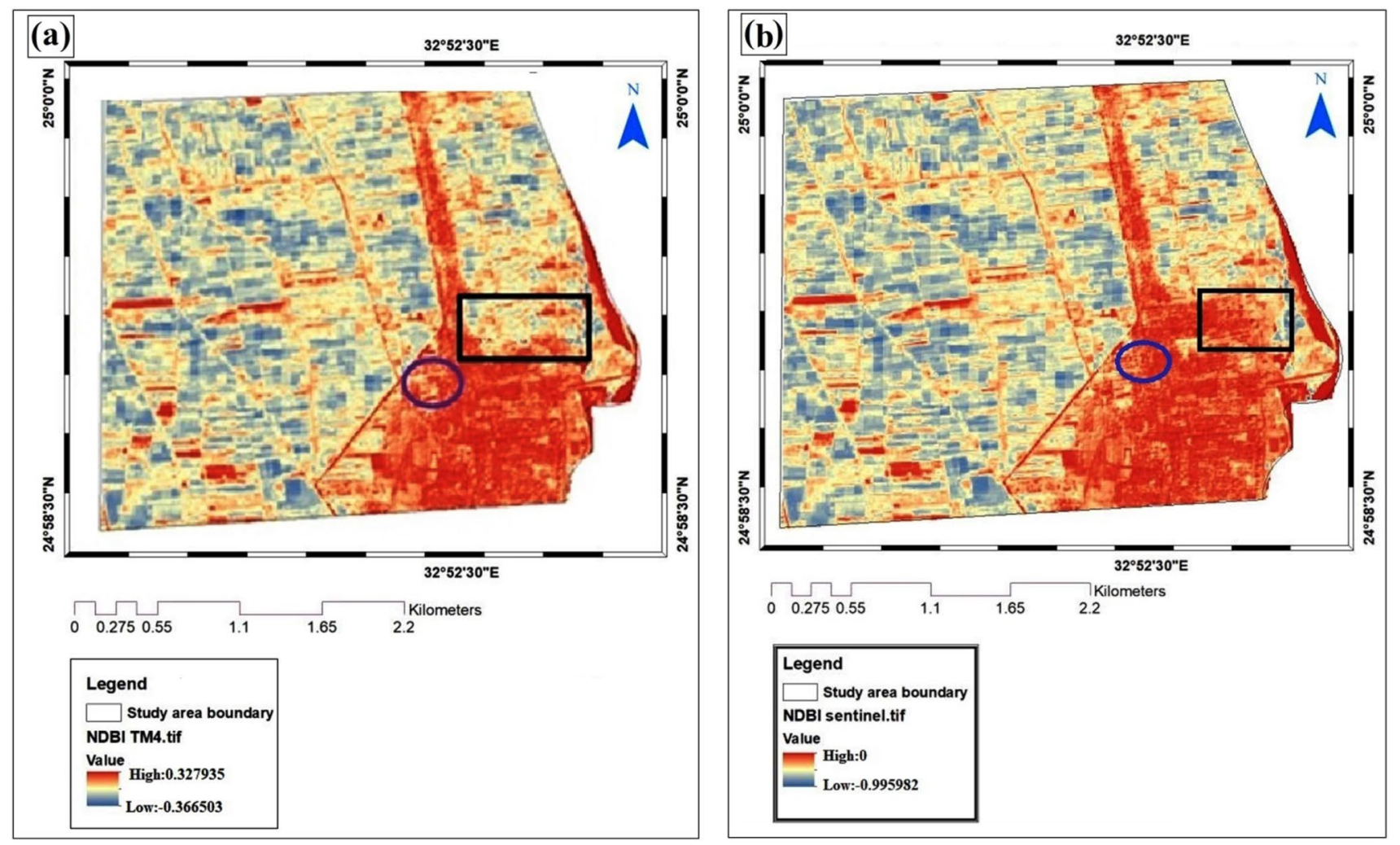

Fig. 9 The changes in the urban area between 1983 (a), and 2019 (b) around the temple by NDBI index

some suggestions that can use around the heritage sites to protect these sites and to create perfect archaeological map include the service regions around these sites. Also, some researchers put some new recommendations for protecting cultural heritage sites such as some engineering systems [112-114]. The suggested model includes three boundaries around the temple to examine the current building near the temple. It is believed that the right approach to handling the situation is the application of the concept of "biosphere reserves" as proposed and adopted by the UNESCO Man and Biosphere Program (MAB). This objective can be made by a "Zonation System" in the Edfu area that applies different management policies to different zones. Generally, the definition of the Zonation system is the system that composite from some areas that can put around the heritage sites for protecting against the environmental risk such as groundwater, urban or agriculture sprawling etc., We have many and many environmental status, so we have the opportunity to change the buffer line distances. On the other hand, we have many kinds of heritage sites, so the same situation as the environmental status. For example, in Egypt we have many archaeological sites in North (Irrigated area), South (Irrigated and desert areas). So, according to the environmental setting, we can choose the distance between the buffer zones. But generally, we have not standard distance for every kind of the environmental setting. UNESCO has identified the buffer zone around the archaeological sites to be $100 \mathrm{~m}$. Generally, the buffer zone is identified on basis of the surrounding activities considering the anthropogenic and environmental conditions. Edfu Template is surrounded by built-up and agricultural areas, thus the buffer zone is proposed to be decreased from 100 to $50 \mathrm{~m}$ with stiff control to minimize the impact the might result from the activities in these regions. The first area is sited between the archaeological temple and core area (monitoring). The second area is between the buffer zone and core area including research, education, and training station and human settlements. Finally, the third area is between the buffer zone and transition zone (tourism and recreation) (Fig. 12). 

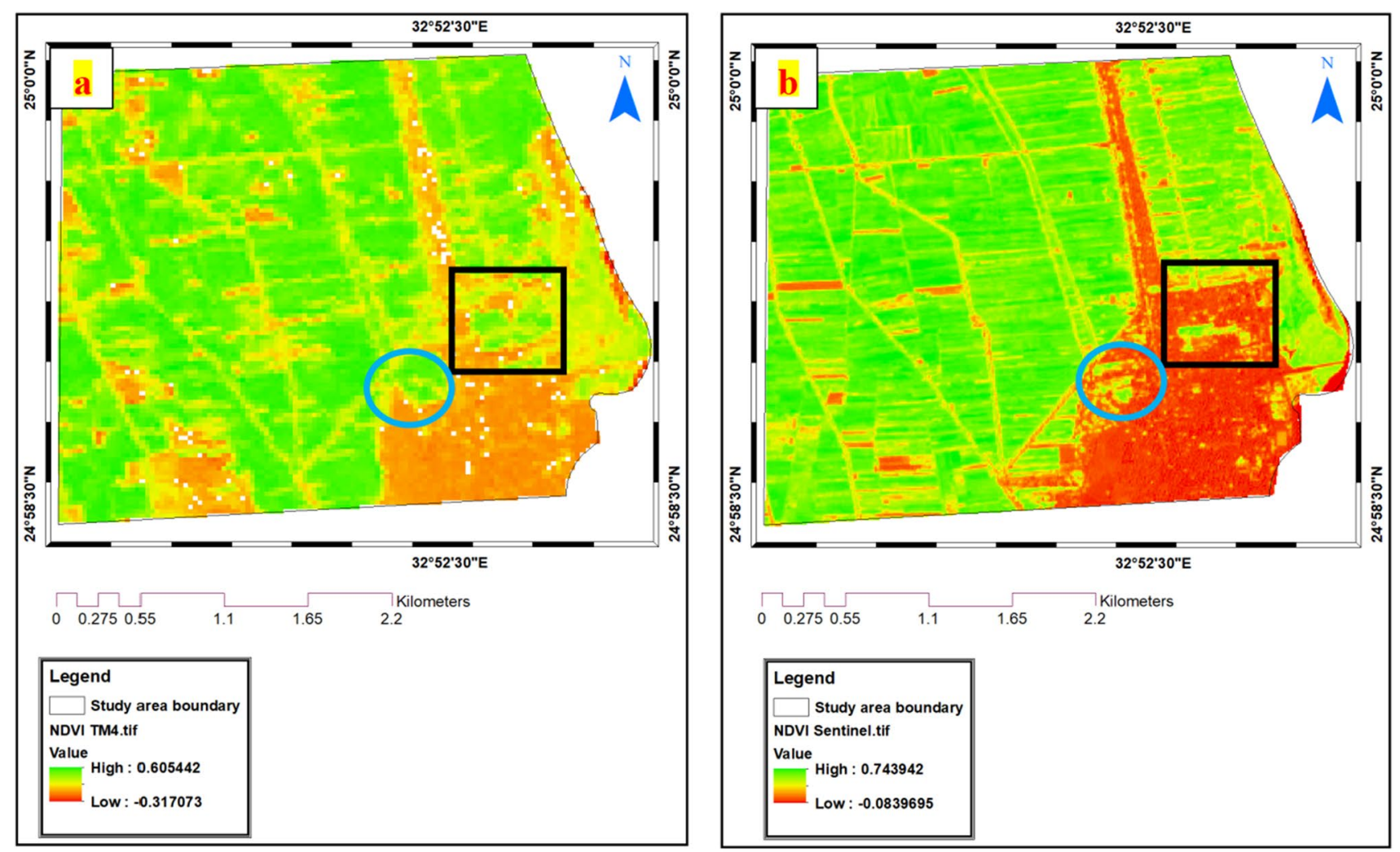

Fig.10 The changes in the agriculture area between 1983 (a), and 2019 (b) around the temple by NDVI index

Fig. 11 Classical method for the groundwater catchment shows the digging near the temple walls (a), and The distance between the pump and the temple wall about $3 \mathrm{~m}$ (b) (https://www.cdmsmith.com/ en/Client-Solutions/Projects/ Temple-of-Edfu-Groundwate r-Lowering)

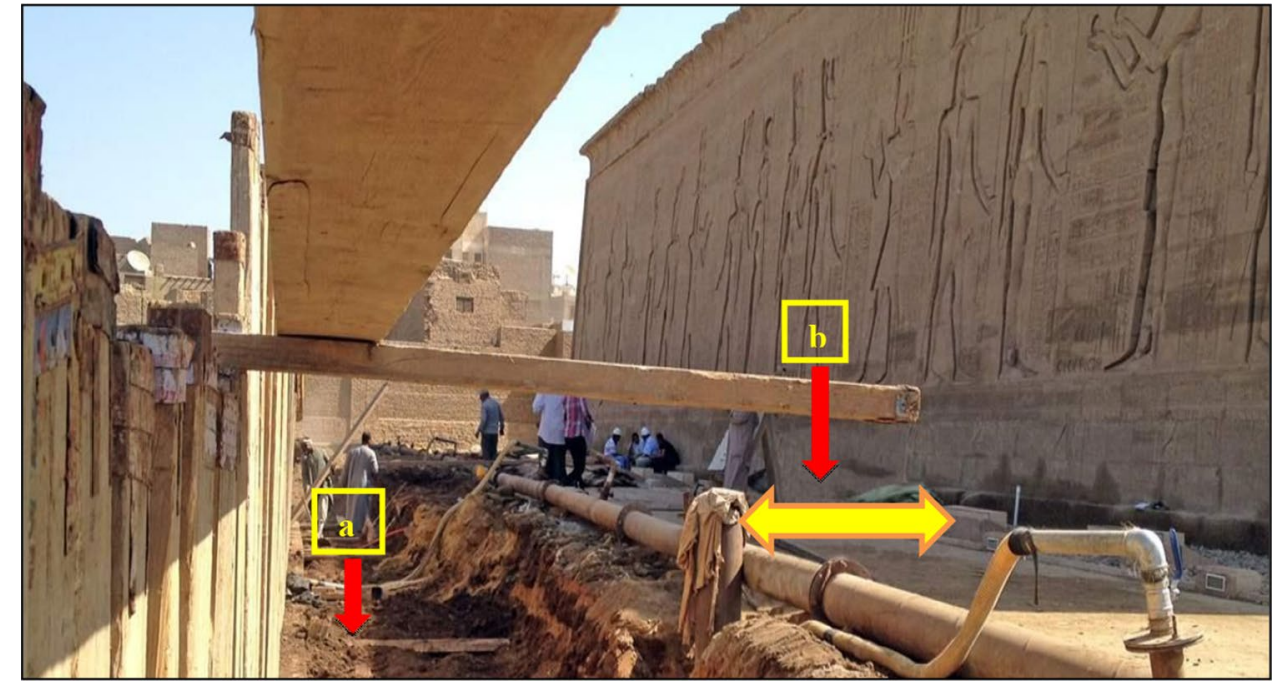


Fig. 12 GIS model to detect the buffer and suggested zonation areas around the Horus temple

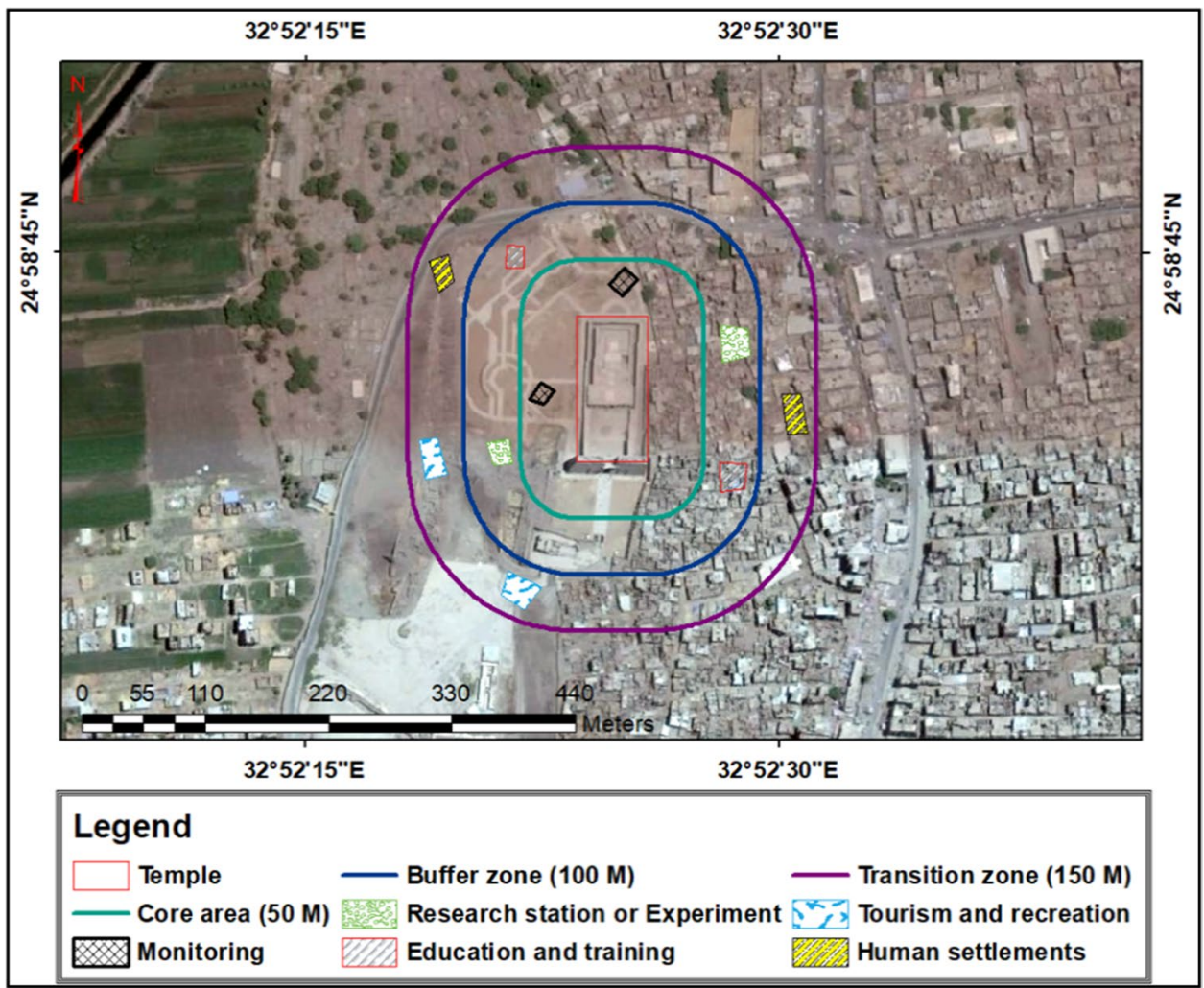

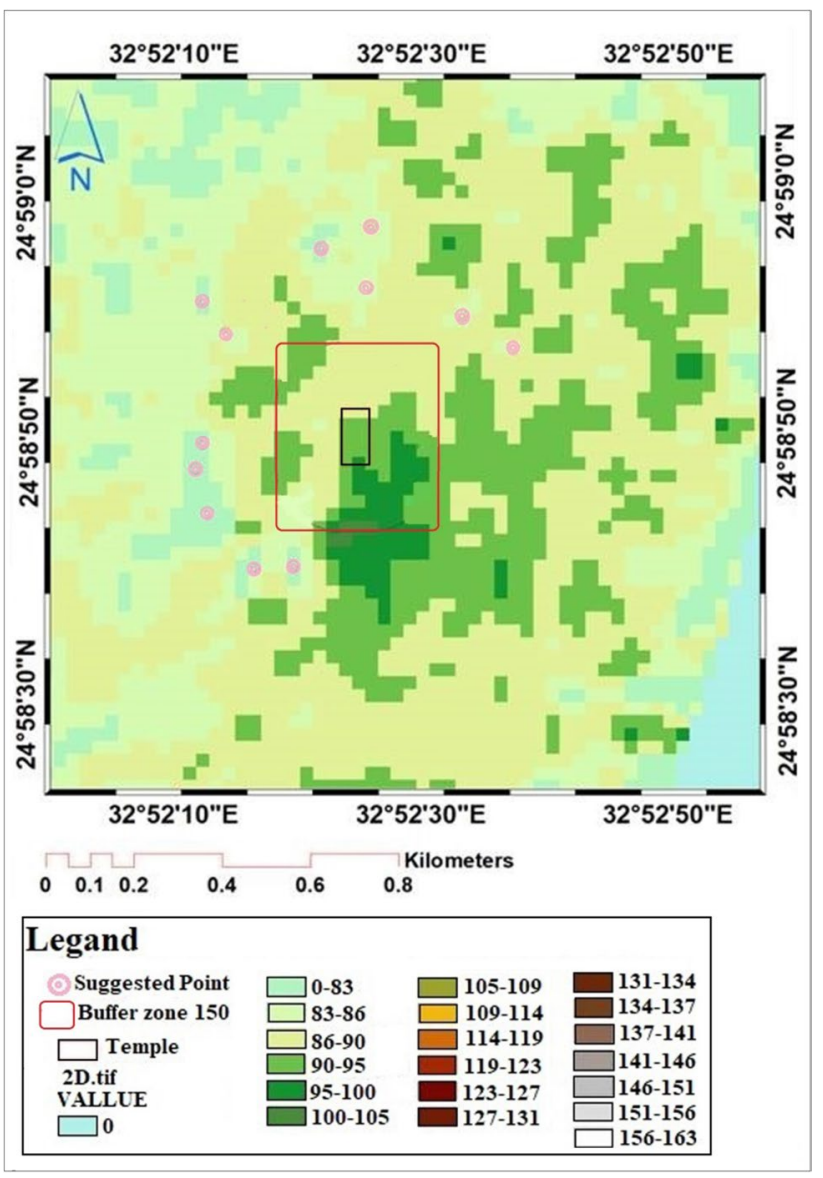

Fig. 13 Selected points as trenches by SRTM for the study area
The surrounding area of the temple is affected by agricultural drainage and built-up sewage. The GIS model is created to implement the subsurface drainage system around the temple. This model proposes collecting groundwater by choosing some points as trenches (Fig. 13). The suggested points will collect the water slowly; this water will be collected by the pump line connected finally with the water recycling station (Fig. 14).

\section{Conclusion}

In this study, multisource satellite images, hydrogeological and geological data set were used and operationally applied for investigating the environmental risks around Edfu Temple. Results of the present study showed that urban sprawl on account of the agricultural lands represent the main source inducing the environmental degradation in the areas surrounding the archaeological sites. Both of them strongly influence the distribution in the levels of groundwater which are considered the main causes of the deterioration process affecting the Temple. Processing of multi-temporal satellite imagery provided the necessary information on anthropogenic and natural activities around the archaeological sites which helps to sustain these resources. The joint analyses of the outputs from the diverse disciplines along with in situ investigations provide the 
Fig. 14 The proposed model shows the suggested points for the trenches and the total method by GIS model and Google earth Plus 2019

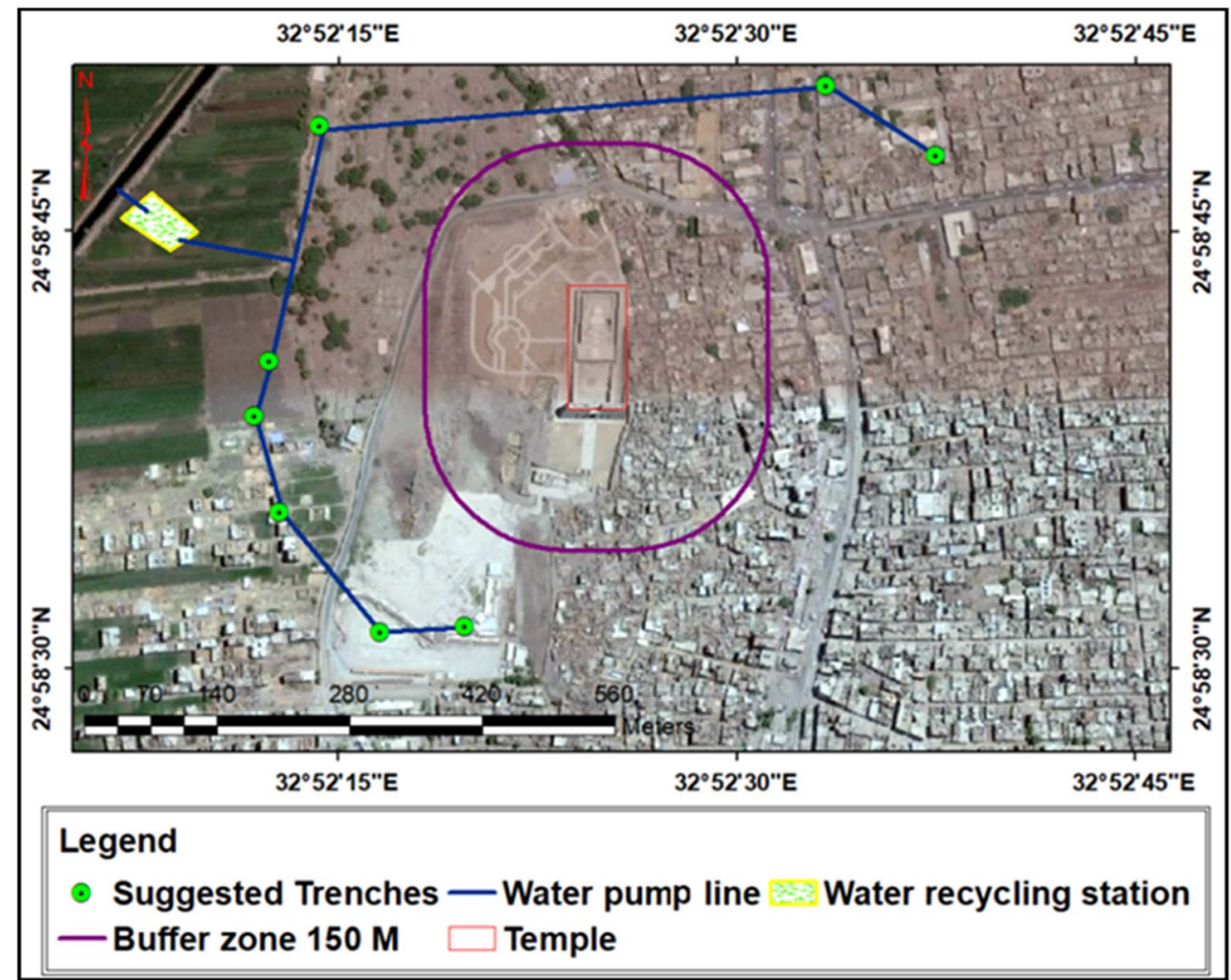

current environmental conditions and their interrelationships with the temple deterioration. For mitigation measures, the present study adopted an integrated approach based on remotely sensed data processing, archaeological, hydrological and geological analyses to propose practical innovative solutions to conserve the historic sites.

\section{Compliance with ethical standards}

Conflict of interest The author declares that they have no competing interest.

\section{References}

1. Woodward JC, Macklin MG, Krom MD, Williams MAJ (2007) The Nile: evolution, quaternary river environments and material fluxes. In: Gupta A (ed) Large rivers: geomorphology and management. Wiley, Chichester, pp 261-291

2. Zaki R (2007) Pleistocene evolution of the Nile Valley in northern Upper Egypt. Quat Sci Rev 26:2883-2896. https://doi. org/10.1016/j.quascirev.2007.06.032

3. Welc F, Marks L (2014) Climate change at the end of the Old Kingdom in Egypt around 4200 BP: new geoarchaeological evidence. Quat Int 324:124-133. https://doi.org/10.1016/j.quain t.2013.07.035

4. USDA US (1976) Department of Agriculture cooperating with U.S. Agency for International Development. EMA "Egyptian Ministry of Agriculture", Egypt, major constraints to increasing agricultural productivity, Foreign Agricultural Economic Report No. 120, PN-AAG-714.

5. Sallam GA (2003) Quality control and quality assurance of subsurface drainage Projects in Egypt. Diffuse Pollut Conf Dublin 2003:3-149

6. Nasr ML (1997) Social dimensions of the policy of the use of water, Options Méditerranéennes, SéE A /n031, 1997 Séminaires Méditerranéens.

7. Crush J (1995) Power of development. Jonathan Crush and Contributors, New York, p 323

8. Hegazi AM, El Bagouri (2002) National action plan for combating desertification, provisional, Arab Repulblic of Egypt, 41 p.

9. Abu-Zeid MA (1997) Egypt's water policy for the 21st century. IXth World Water Congress of IWRA, a special session on Water management under scarcity conditions: the Egyptian experience, Montreal, Canada, September 1997. https://doi. org/10.1080/07900629749836

10. Awad MA, El Arabi NE, Mokhtar S, Hamza B (1997) Use of solute chemistry and isotopes to identify sources of groundwater recharge in the Nile Aquifer Sysytem. Upper Egypt Ground Water 35(N2):223. https://doi.org/10.1111/j.1745-6584.1997. tb00078.x

11. Farrag AA (1982) Hydrogeological studies on the Quaternary water -bearing sediments in the area between Assiut and Aswan. MSc Thesis, Geology Department, Assiut University, Egypt

12. Farrag AA (1991) Hydrogeology of the Nile Basin between Assiut and Qena, Upper Egypt. PhD Thesis, Hydrogeology and Engineering Geology Department, Charl Uniersity, Prague, Chech Republic

13. Attia B (2002) Baseline study of water resources in Qena. Report submitted to Egyptian Environmental Affair Agency, funded by SEAM Programme. Ministry of State for Environment, Cairo. 
14. Helmy I, El Shahat A (1996) Groundwater impact on Luxor Temple. The first International conference of Control of rising groundwater problem in urbanized areas. Faculty of Engineering. Mansoura University, Egypt, pp 147-157

15. Abu El Ella EM (1989) Hydrogeochemistry of the River Nile in the area between Aswan and Assiut. PhD Thesis, Geology Department, Faculty of Science, Assiut University, Egypt.

16. Abu El-Ella EM (1990) Chemistry of the Nile water between Aswan and Assiut, upper Egypt. Bull Fac Sci Assiut Univ 10 (2-F):35-49.

17. Abu El-Ella EM (1993) Evaluation of groundwater chemistry in the area southwest of Qena City, Egypt. Bull Fac Sci Assiut Univ 22(1):1-14

18. Shahin M (1991) Assessment of groundwater resources in Egypt. IHE Report Series no. 23. The Netherlands: International Institute for Hydraulic and Environmental Engineering

19. Abadi SA (1995) Geological and hydrogeological studies in the area between longitude $32^{\circ} 18^{\prime}-32^{\circ} 20^{\prime} \mathrm{E}$ and Latitude $25^{\circ} 28^{\prime}-26^{\circ} 00^{\prime} \mathrm{N}$, Nag Hammadi, Egypt. MSc Thesis, Geology Department, Faculty of Science, Assiut University.

20. Abadi SA (1999) Detailed hydrogeological studies on the area located between latitudes $25^{\circ} 50^{\prime} \& 26^{\circ} 5^{\prime} \mathrm{N}$ and longitude $32^{\circ}$ $10^{\prime} \& 32^{\circ} 30^{\prime} \mathrm{E}$, Qena Governorate, Upper Egypt. PhD Thesis, Geology Department, Faculty of Science, Assiut University.

21. Awad MA, Nada AA, Hamza MS, Froehlich K (1995) Chemical and isotopic investigation of groundwater in Tahta region, Sohag. Egypt Isotope and Radiation Res Manuscript No 355. https://doi.org/10.1007/BF00126083

22. Ahmed AA (1992) Geophysical and hydrogeological studies in the area southeast of Sohag, Egypt. MSc Thesis, Geology Department, Faculty Science, Sohag, South Valley University, Egypt.

23. Ahmed AA (2003) The impact of hydrogeological conditions on the archaeological sites at some localities between Qena and Aswan, Egypt. PhD Thesis, Geology Department, Faculty of Science, South Valley University, Sohag, Egypt.

24. Elewa SA (2004) Effect of the construction of Aswan High Dam on the groundwater in the area between Qena and Sohag, Nile Valley, Egypt. PhD Thesis, Faculty Science, Assiut University, Egypt.

25. Kamel ER (2004) Geology of Luxor area and its relationship to groundwater uprising under the Pharaohs Temples. MSc Thesis, Aswan Faculty of Science, South Valley University, Egypt

26. Ali AM (2005) Evaluation of the Nile Valley aquifer from Aswan to Assiut using geographical and hydrogeological methods. PhD, Geology Departnent, Faculty of Sci, South Valley University, Aswan, Egypt.

27. Ali AM (2005a) Geochemical characteristics of the surfacial Nile basin sediments and their environmental relevance, Sohag area, Egypt. MSc Thesis, Faculty of Science, South Valley University, Egypt.

28. EEAA (Ministry of State for Environmental Affairs) (2005) Qena Governorate Environmental Action Plan. Egyptian Environmental Affairs Agency, SEAM Programme, Entec UK Ltd., ERM

29. Ismail A, Anderson NL, Rogers JD (2005) Hydrogeophysical Investigation at Luxor. Southern Egypt JEEG 10(1):35-49. https ://doi.org/10.2113/JEEG10.1.35

30. Abdel Rahman AA (2006) Hydrogeological and geophysical assessment of the reclaimed areas in Sohag, Nile Valley, Egypt. PhD Thesis, Geology Department, Faculty of Science, Ain Shams University, Cairo,Egypt

31. Brikowski TH, Faid A (2006) Pathline-calibrated groundwater flow models of Nile Valley aquifers, Esna. Upper Egypt J Hydrol 324(2006):195-209. https://doi.org/10.1016/j.jhydr ol.2005.10.011
32. Abdallah FA, Ahmed AA, Omer AA (2009) Degradation of groundwater quality of quaternary Aquifer at Qena, Egypt. J Environ Stud 1:19-31

33. Abd El-Bassier MA (1997) Hydrogeological and hydrogeochemical studies of the Quaternary aquifer in Qena Governorate, Egypt. MSC Thesis, Geology Department, Faculty of Science, Assiut University, Egypt.

34. Campos EH (2009) A groundwater flow model for water related damages on historic monuments - case study West Luxor Egypt. Institutionen för Teknisk Vattenresurslära Lunds Tekniska HögskolaLunds Universitet, Department of Water Resources Engineering, Faculty of Engineering, Lund University, Lund, Sweden.

35. Ahmed AA, Omer A, Yosef AM, Rez S (2010) Lead in groundwater of sohag governorate, Egypt. The 15th Annual Conference on "Management of water crises and water water resources", 11-12 December 2010, Ain Shams University, Egypt.

36. Ahmed AA, Ali MH (2011) Hydrochemical evolution and variation of groundwater and its environmental impact at sohag area. Egypt Arab J Geosci 4(3-4):339-352. https://doi. org/10.1007/s12517-009-0055-z

37. Hamdan AM (1999) Hydrogeological and geophysical studies for the evaluation of groundwater aquifer in wadi El Saaida, Edfu, Aswan, Egypt. MSC Thesis, Geology Department, South Valley University, Aswan, Egypt.

38. Masoud AM, Abdel Moneim AA, Ahmed AA, Youssef AM (2010) Evaluation of Hydrogeological Conditions in the desert area west of Armant, Upper Egypt, The 4th International Conference on Healthy Water in Arab World (Water for Healthy Arab Citizens), 21-22 June 2010, Semiramis Intercontinental, Cairo, Egypt, Corniche El Nil , Cairo, Egypt, Arab Healthy Water Association.

39. Omer AA, Ahmed AA, Yosef AM, Rez S (2010) Nitrates, ammonia and phosphates in groundwater of Sohag Governorate, Egypt: sources and health impact. In: The 4th International Conference on Healthy Water in Arab World (Water for Healthy Arab Citizens), 21-22 June 2010, Semiramis IntercontinentalCairo, Egypt, Corniche El Nil , Cairo, Egypt, Arab Healthy Water Association.

40. Rizk SM (2010) Assessment of the groundwater quality in Sohag Governorate, Egypt: A study in the environmental geochemistry. MSc Thesis, Geology Department, Faculty of Science, Sohag University, Egypt.

41. Shamrukh M, Corapcioglu MY, Hassona FA (2001) Modeling the effect of chemical fertilizers on groundwater quality in the Nile Valley aquifer, Egypt. Groundwater 39(1):59-67. https:// doi.org/10.1111/j.1745-6584.2001.tb00351.x

42. Ismaeil MB, Abdel Moneim AA (1998) Environmental deterioration of Karnak TemplesLuxor, Upper Egypt. Bul Fac Eng Assiut Univ 1:273-302. https://doi.org/10.1007/s12517-013-0962-x

43. Levin N (1999) Fundamentals of Remote Sensing, p. 8. https:// www.geoservis.ftn.uns.ac.rs/downloads/ISP/1999-fundamenta Is-of-remote-sensing.pdf.

44. Skidmore A (2003) Environmental modeling with GIS and remote sensing, published In the USA and Canada, second publishing, p. 8.

45. Johnson JK (2006) Remote sensing in archaeology. The University of Alabama Press, Tuscaloos Published for The Center for Archaeological Research at the University of Mississippi, Mississippi, p. 130

46. Mosbeh IRH, Kaloop R (2015) Monitoring urban growth and land use change detection with GIS and remote sensing techniques in Daqahlia governorate Egypt, Gulf Organisation for Research and Development. Int J Sustain Built Environ 4:117124, 118. https://doi.org/10.1016/j.ijsbe.2015.02.005 
47. Orlando P, Villa B (2011) Remote sensing applications in archaeology. Archeol Calcolatori 22:147-168

48. Alexakis DD, Agapiou A, Hadjimitsis DG, Sarris A (2012) Remote sensing applications in archaeological research. ISBN: 978-95351-0651-7. Intech. Available from:https://www.intechopen .com/books/remote-sensingapplications/remote-sensingapplications-in-archaeology, p. 435.

49. Khorram S, Koch FH, van der Wiele CF, Nelson SAC (2012) Remote sensing, Library of Congress control number: 2012930489. Springer, Berlin, $p 76$

50. Butt A, Shabbir R, Ahmad S, Aziz N (2015) Land use change mapping and analysis using remote sensing and GIS: a case study of Simly watershed, Islamabad, Pakistan. Egypt J Remote Sensing Space Sci 18(2):252. https://doi.org/10.1016/j. ejrs.2015.07.003

51. Wiseman J, El-Baz F (2007) Remote sensing in archaeology, Library of Congress control number: 2001012345. Springer Science, Berlin, p 71.

52. Kelong T, Yuqing W, Lin Y, Riping Z, Wei C, Yaobao M (2008) A new archaeological remote sensing technology, the International archives of the photogrammetry. Remote Sensing and Spatial Information Sciences, XXXVII, Part B7, Beijing, p 221.

53. Parcak SH (2009) Satellite remote sensing for archaeology, First published 2009 by Routledge, Milton Park. Simultaneously published in the USA and Canada by Routledge, p. 38. https:// doi.org/10.4324/9780203881460

54. Akin A, Clarke KC, Berberoglu S (2014) The impact of historical exclusion on the calibration of the SLEUTH urban growth model. Int J Appl Earth Obs Geoinf 27(PART B): 156-168. https ://doi.org/10.1016/j.jag.2013.10.002

55. Hritz C (2014) Contributions of GIS and satellite-based remote sensing to landscape Archaeology in the Middle East, 22(3). https://doi.org/10.1007/s10814-013-9072-2

56. Farrag AEA, Megahed HA, Darwish MH (2019) Remote sensing, GIS and chemical analysis for assessment of environmental impacts on rising of groundwater around Kima Company, Aswan, Egypt. Bull Natl Res Centre 43(1):14. https://doi. org/10.1186/s42269-019-0056-3

57. Papoutsa C, Akylas E, Hadjimitsis D (2014) Trophic State Index derivation through the remote sensing of Case-2 water bodies in the Mediterranean region. Cent Eur J Geosci 6(1):67-78. https://doi.org/10.2478/s13533-012-0161-4

58. Tapete D, Cigna F (2017) Trends and perspectives of spaceborne SAR remote sensing for archaeological landscape and cultural heritage applications. J Archaeol Sci Reports 14:716726. https://doi.org/10.1016/j.jasrep.2016.07.017

59. Cerrillo-Cuenca E (2017) An approach to the automatic surveying of prehistoric barrows through LiDAR. Quat Int 435:135-145. https://doi.org/10.1016/j.quaint.2015.12.099

60. Malfitana D, Leucci G, Fragalà G, Masini N, Scardozzi G, Santagati C, Shehi E (2015) The potential of integrated GPR survey and aerial photographic analysis of historic urban areas: A case study and digital reconstruction of a Late Roman villa in Durrës (Albania). J Archaeol Sci Reports 4:276-284. https ://doi.org/10.1016/j.jasrep.2015.09.018

61. Kurth D (2004) The Temple Of Edfu: Aguide By An Ancient Egyptian Priest. American Univ in Cairo Press.

62. Jelinková EAE. (1962) The Shebtiw in the temple at Edfu. Zeitschrift für Ägyptische Sprache und Altertumskunde 87(12):41-54. https://doi.org/10.1524/zaes.1962.87.12.41

63. Shaltout M, Belmonte JA (2005) On the orientation of ancient Egyptian temples: (1) Upper Egypt and Lower Nubia. J Hist Astron 36(3):273-298

64. Bey M (1890) The monuments Upper Egypt, pp.1-384.
65. Randy SHL (2014) The Behdetite: a study of horus the behdetite from the old kingdom to the conquest of Alexander. The University of Chicago.

66. Finnestad RB (1985) Image of the World and Symbol of the Creator: On the Cosmological and Iconological Values of the Temple of Edfu (Vol. 10). Otto Harrassowitz Verlag.

67. Porter B, Moss RLB (1972) Topographical bibliography of ancient Egyptian hieroglyphic texts, reliefs, and paintings (Vol. 2). Clarendon Press, Oxford.

68. Manning JG (1999) The land-tenure regime in Ptolemaic Upper Egypt. In: Proceedings-British academy, vol. 96, pp. 83-106. Oxford University Press inc., Oxford.

69. Reymond EA (1969) The mythical origin of the Egyptian temple. Manchester University Press, Manchester.

70. Coppens F (2009) Temple festivals of the Ptolemaic and Roman periods.

71. Byl Sh (2012) The essence and use of perfume in ancient Egypt, submitted in accordance with the requirements for the degree of master of arts in the subject ancient near eastern studies at the university of south Africa, pp 1-413. https ://hdl.handle.net/10500/8105

72. Blackman AM, Fairman HW (1946) The Consecration of an Egyptian Temple according to the Use of Edfu. J Egyptian Archaeol 32(1):75-91. https://www.jstor.org/stable/3855419

73. Wong JY (2016) Raze of Glory: interpreting Iconoclasm at Edfu and Dendera. J Late Antiquity 9(1):89-131. https://doi. org/10.1353/jla.2016.0000

74. Clarysse W (2010) Egyptian temples and priests: GraecoRoman. In: Lioyds AB (ed)A companion to ancient Egypt, vol 1. wiley, Chicester, pp 274-290.

75. Fairman HW (1935) The Myth of Horus at Edfu. J Egyptian Archaeol 21(1):26-36. https://doi.org/10.1177/0307513335 02100103

76. Karl B (2007) Egypt : handbook for travellers, Institute of Museum and Library Services (IMLS) and the Computer and Information Technology Institute (CITI), Rice University, pp.1-379.

77. Fairman RW (1954) Worship and festivals in an Egyptian temple, An expanded version of a lecture given at the John Rylands Library on Wednesday the 13th of January.

78. Ahlbäck T (1996) Dance, Music, Art, and Religion Based on Papers Read at the Symposium on Dance, Music, and Art in Religions Held at Åbo, Finland, on the 16th-18th August 1994, Published by The Donner Institute for Research in Religious and Cultural History Åbo Finland Distributed by Almqvist \& Wiksell International Stockholm, Sweden, pp.1-426.

79. El-Gohary M (2015) Effective roles of some deterioration agents affecting Edfu royal birth house 'Mammisi'. Int J Conserv Sci 6(3):349-368

80. Senosy M, Felesteen A, Hamdan A (1998) Application of electrical resistivity method in ground water elevation of Wadi ElSa'ayda area, northwest of Idfu. Egypt Bull Fac Sci Assiut Univ 27(2):121-145

81. Farrag A (2005) The hydraulic and hydrochemical impacts of the Nile system on the groundwater in upper Egypt. Assute Univ Bull Environ Res 8(1):87-102

82. El-Gohary MA (2016) A holistic approach to the assessment of the groundwater destructive effects on stone decay in Edfu temple using AAS, SEM-EDX and XRD. Environ Earth Sci 75(1):1-11. https://doi.org/10.1007/s12665-015-4849-x

83. El-Shishtawy A, Atwia M (2013) Impact of soil and groundwater corrosion on the Hierakonpolis temple town archaeological site, Wadi Abu Sufian, Idfu, Egypt. Environ Monit Assess 185:4491-4511. https://doi.org/10.1007/s10661-012-2884-6 
84. Coral CONOCO Company EGP (1987) Geological map of Egypt scale 1:500000. Egypt, Cairo

85. Research Institute for Groundwater (RIGW) (1990) "Potentialty of Groundwater in El Minya area" note, 3.Interal Report. Groundwater Development West Tahta. Water Bbalance Study, Technical note 60:124-188

86. Groundwater I (2012) Database 1997-2010. Edfu unit, Egypt

87. Wright DK, Kim JKJPJYJ (2020) Spatial modeling of archaeological site locations based on summed probability distributions and hot-spot analyses: a case study from the Three Kingdoms Period, Korea. J Archaeol Sci 113. https://doi.org/10.1016/j. jas.2019.105036

88. Sánchez-Martín J-M, Rengifo-Gallego J-I, Blas-Morato R (2019) Hot spot analysis versus cluster and outlier analysis: an enquiry into the grouping of rural accommodation in extremadura (Spain). ISPRS Int J Geo-Inf 8:176. https://doi.org/10.3390/ijgi8 040176

89. Tewara MA, Mbah-Fongkimeh PN, Dayimu A (2018) Small-area spatial statistical analysis of malaria clusters and hotspots in Cameroon; 2000-2015. BMC Infect Dis 18:636. https://doi. org/10.1186/s12879-018-3534-6

90. Songchitruksa P, Zeng X (2010) Getis-Ord spatial statistics to identify hot spots by using incident management data. Transp Res Rec J Transp Res Board 2165:42-51. https://doi. org/10.3141/2165-05

91. Getis A, Aldstadt J (2004) Constructing the spatial weights matrix using a local statistic. Geog Anal 36(2):90-104

92. Zha Y, Gao J, Ni S (2003) Use of normalized di ff erence built-up index in automatically mapping urban areas from TM imagery. Int J Remote Sens 24:583-594. https://doi.org/10.1080/01431 160304987

93. As-syakur AR, Adnyana IWS, Arthana IW, Nuarsa IW (2012) Enhanced built-UP and bareness index (EBBI) for mapping built-UP and bare land in an urban area. Remote Sens 4(10):2957-2970. https://doi.org/10.3390/rs4102957

94. Hammad FA, El Fakharany MA, Shabana AR, Saleh AA (2015) Hydrogeological studies on Esna-Idfu area, East Nile valley, Eastern Desert, Egypt.The first international conference of the Assuit University, Faculty of Science, Geology Department, vol 16, No. 2, pp. 235-245.

95. Abdel Kader A (2001) Application of some geophysical and hydrogeological techniques for groundwater resources investigation in selected areas between Idfu-Marsa Alam, Eastern Desert, Egypt. MSc Thesis, Assiut University., Faculty of Science, Geology Department, pp 173.

96. Abdel Kareem W (2000) Chemical and Isotopic Investigation of groundwater Aquifers in Idfu Region on the fringes of Qena Governorate. MSc Thesis Geology Department, Faculty of Science, Cairo University, Cairo, Egypt, 137 p.

97. Abdel Moneim AA (1988) Hydrogeology of the Nile Basin in Sohag Province. MSc Thesis, Geology Department, Faculty of Science, Assiut University, Egypt.

98. Abdalazem AH, Gamee MA, Hamdan A, Awad AAM, Mohamed AG (2020) Groundwater Quality Assessment for Irrigation in West Edfu Region, Aswan, Egypt. Assiut J. Agric. Sci 51(1). www. aun.edu.eg/faculty_agriculture/journals_issues_form.php

99. Aly AIM, Froehlich K, Nada A (1993) Study of environmental isotope distribution in the Aswan High Dam Lake (Egypt) for estimation of evaporation of lake water and its recharge to adjacent groundwater. Environ Geochem Health 15:37-49. https://doi.org/10.1007/BF00146291

100. Schweinfurth $G$ (1883) Ueber die geologische Schichtengliederung des Mokattam bei Cairo. Zeitschrift der Deutschen Geologischen Gesellschaft, pp. 709-734.
101. Blanckenhorn M (1901) Neues Zur geologic and palaontologic Aegyptens, Das Miozan. Zeitschr Deutschen Geol Gesellm 53:52-132

102. Barron T (1907) The topography and geology of the district between Cairo and Suez. Egypt, Survey Department, Cairo, p 12

103. Sandford KS, Arkell WJ (1939) Paleolithic man and the Nile Valley in Lower Egypt. Astudy of the region during Pliocene and Pleistocene time, 36. Chicago University Press, Chicago, p. 105.

104. World Health Organization (WHO) (2004) Guidelines for drinking water quality, Vol. 1. Recommendations, 3rd edn. World Health Organization, Geneva.

105. Megahed HA, Farrag AEA (2019) Groundwater potentiality and evaluation in the Egyptian Nile Valley: case study from Assiut Governorate using hydrochemical, bacteriological approach, and GIS techniques. Bull Natl Res Centre 43(1):48. https://doi. org/10.1186/s42269-019-0091-0

106. Bery A, Saad R (2012) Clayey sand soil's behaviour analysis and imaging subsurface structure via engineering characterizations and integrated geophysicals tomography modeling methods. Int J Geosci 3(1):93-104. https://doi.org/10.4236/ijg.2012.31011.

107. Adhikary S, Khan M, Arobe S, Dey S, Billah S (2019) Soil chemical analysis of Kazi and Kazi organic tea garden and compared to ordinary tea gardens of Bangladesh. Open J Soil Sci 9:91-102. https://doi.org/10.4236/ojss.2019.96006.

108. Abu Seif S (2015) Geological evolution of Nile Valley, west Sohag, Upper Egypt: a geotechnical perception. Arab J Geosci 8:11049-11072. https://doi.org/10.1007/s12517-015-1966-5

109. Hemeda S, Fahmy A, Moustafa A, Hafez M (2019) The Early Basilica Church, El-Ashmonein Archaeological Site, Minia, Egypt: geo-environmental analysis and engineering characterization of the building materials. Open J Geol 9:157-186. https://doi. org/10.4236/ojg.2019.93011

110. Al- Farraj AS (2011) Mineralogical composition of Limestone rock and soil from Jubaila formation. Asian J Earth Sci 4:203213. https://doi.org/10.3923/ajes.2011.203.213

111. Harbo M, Pedersen J, Johnsen R (2011) Central Denmark Region and Klaus Petersen, Danish Ministry of the Environment Nature Agency. Groundwater in a future climate . pp.1-186.

112. Dore C, Murphy M (2012) Integration of Historic Building Information Modeling (HBIM) and 3D GIS for recording and managing cultural heritage sites. In: 18th International Conference on Virtual Systems and Multimedia, Milan, 2012, pp. 369-376. https://doi.org/10.1109/VSMM.2012.6365947.

113. El-Hakim SF, Beraldin J, Picard M, Godin G (2004) Detailed 3D reconstruction of large-scale heritage sites with integrated techniques. IEEE Comput Graphics Appl 24(3):21-29. https:// doi.org/10.1109/MCG.2004.1318815.

114. Cassar M, Brimblecombe $P$, Nixon T, Price $C$, Sabbioni $C$, Saiz Jimenez C, Van Balen K (2001) Technological requirements for solutions in the conservation and protection of historic monuments and archaeological remains. European Parliament, Kirchberg, Luxembourg

\section{Other links}

115. https://www.egypttoursportal.com/egypt-day-trips/aswan -tours/tour-to-kom-ombo-edfu-temples-from-aswan/

116. https://commons.wikimedia.org/wiki/File:Edfu_Temple_03201 0_21_d2.jpg

117. https://pubs.usgs.gov/gip/gw_ruralhomeowner/

118. https://www.cdmsmith.com/en/Client-Solutions/Projects/ Temple-of-Edfu-Groundwater-Lowering

Publisher's Note Springer Nature remains neutral with regard to jurisdictional claims in published maps and institutional affiliations. 